West Virginia Agricultural and Forestry Experiment Davis College of Agriculture, Natural Resources Station Bulletins

$1-1-1990$

\title{
Wood residues as an energy resource.
}

David Walter Patterson

Gary W.Zinn

Follow this and additional works at: https://researchrepository.wvu.edu/ wv_agricultural_and_forestry_experiment_station_bulletins

\section{Digital Commons Citation}

Patterson, David Walter and Zinn, Gary W., "Wood residues as an energy resource." (1990). West Virginia Agricultural and Forestry Experiment Station Bulletins. 703.

https://researchrepository.wvu.edu/wv_agricultural_and_forestry_experiment_station_bulletins/597 @ WVU. It has been accepted for inclusion in West Virginia Agricultural and Forestry Experiment Station Bulletins by an authorized administrator of The Research Repository @WVU. For more information, please contact ian.harmon@mail.wvu.edu. 


\section{Wood Residues As an Energy Resource}

\section{Part I: A REVIEW OF TECHNOLOGIES}

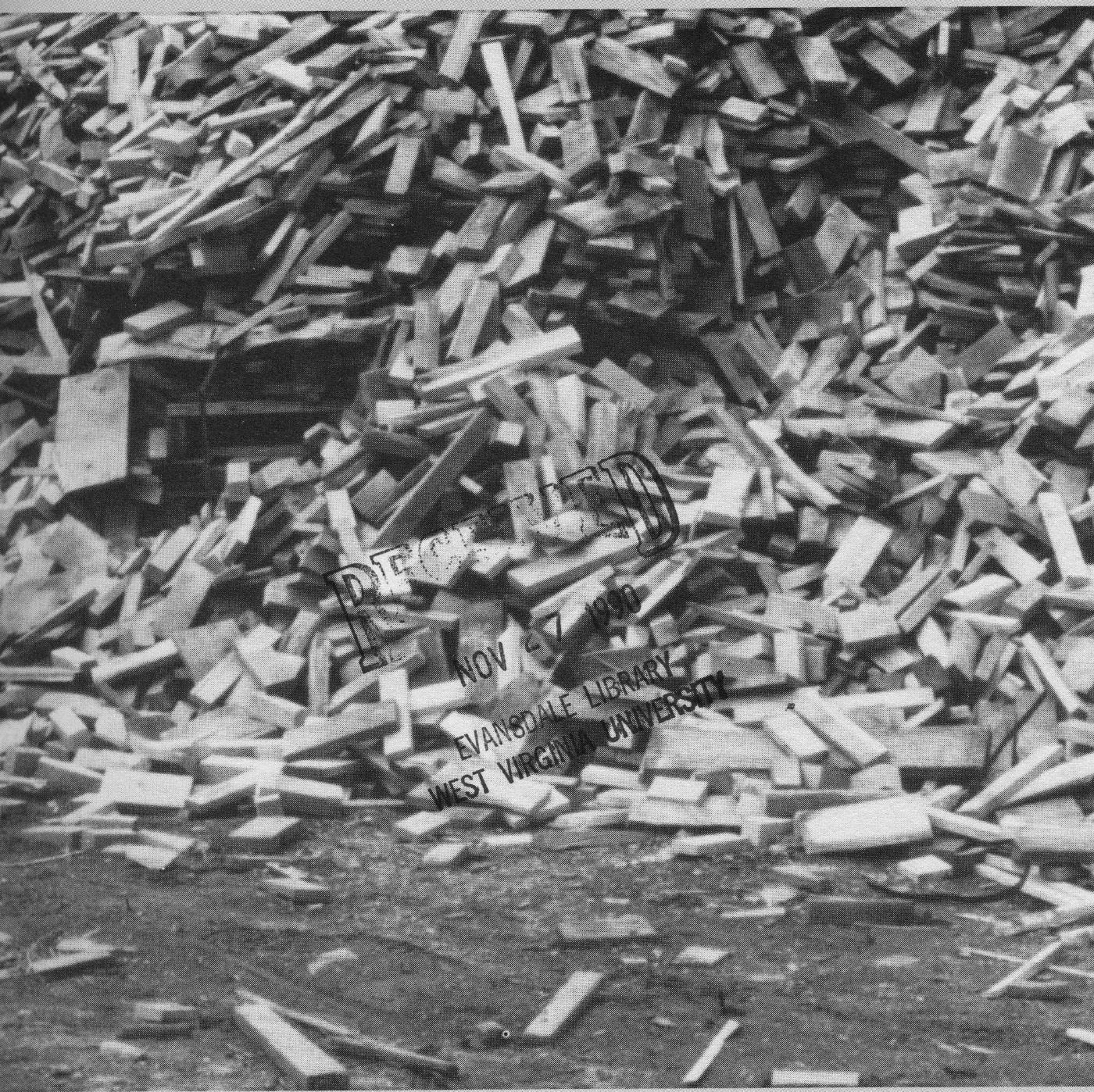

Bulletin 703 . June 1990

Agricultural and Forestry Experiment station West Virginia University 


\section{Authors}

David W. Patterson is Associate Professor of Wood Science and Gary W. Zinn is Professor (retired) of Forest Resources Management, Division of Forestry, College of Agriculture and Forestry, West Virginia University.

This research was supported by a grant from the Energy and Water Research Center of West Virginia University as part of their "Assessment of Energy Technologies for Economic Development in West Virginia" program. The authors would like to acknowledge their appreciation to Joel Stopha and Tamara Kent for their help on the project, and to John Byam of DOE/METC in Morgantown, W.Va., for his help with a computer literature search.

West Virginia University

Agricultural and Forestry Experiment Station

College of Agriculture and Forestry

Robert H. Maxwell, Director

Morgantown 


\section{Wood Residues As an Energy Resource}

PartI: A REVIEW OF TECHNOLOGIES

by

David W. Patterson

and

Gary W. Zinn

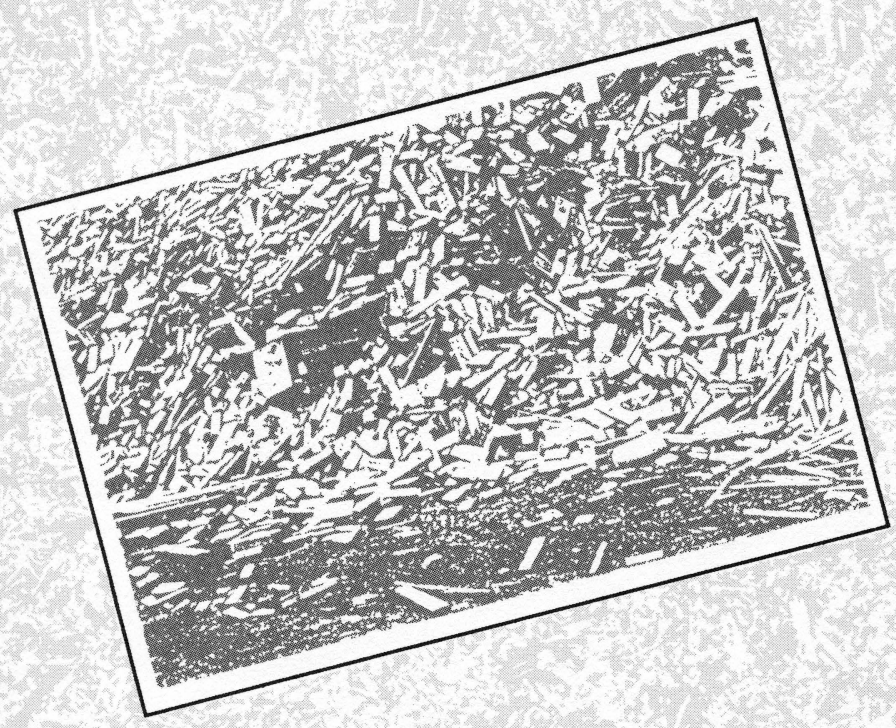

Bulletin 703 - June 1990

Agricultural and Forestry Experiment station West Virginia University 
Blank Page in Original Bulletin 


\section{Contents}

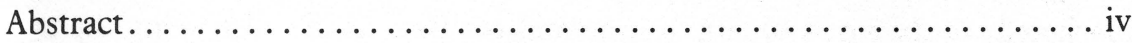

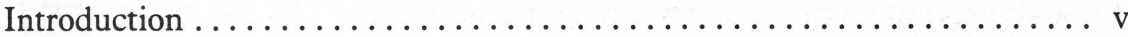

Wood Residues And Their Uses $\ldots \ldots \ldots \ldots \ldots \ldots \ldots \ldots \ldots \ldots$

Wood Combustion ............................... 4

Fuel Value of Wood............................ 4

By-Products of Combustion . . . . . . . . . . . . . . . . . 6

Pollution Control Devices.......................... 9

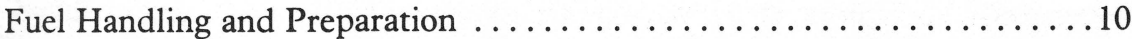

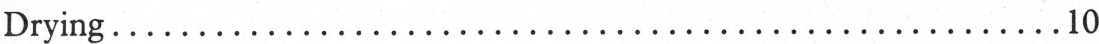

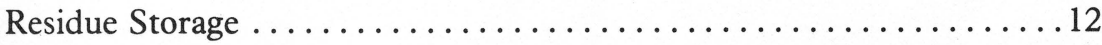

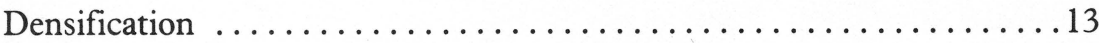

Wood/Coal Densification ............................ 14

Furnaces ...................................... 14

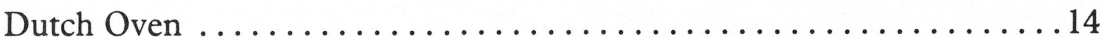

Suspension Furnaces .............................. 15

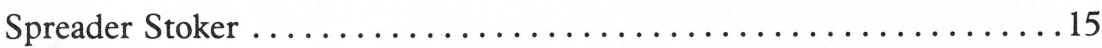

Fluidized Bed .................................

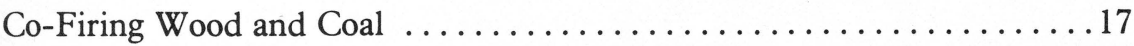

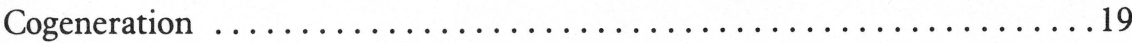

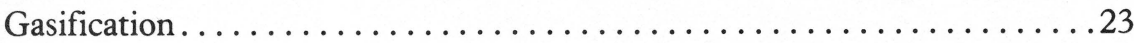

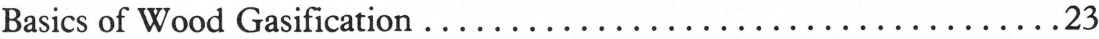

Components of Complete Gasification Systems................24

Wood as a Gasifier Feedstock. . . . . . . . . . . . . . . . . . . . . . . 24

Health and Environmental Consideration .................25

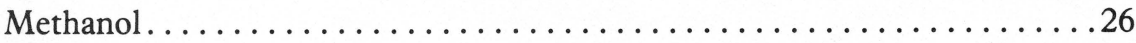

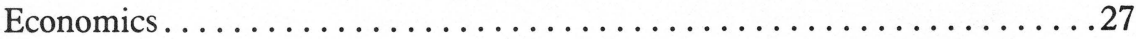

Summary $\ldots \ldots \ldots \ldots \ldots \ldots \ldots \ldots \ldots \ldots \ldots \ldots \ldots \ldots \ldots \ldots \ldots \ldots \ldots \ldots \ldots, 28$

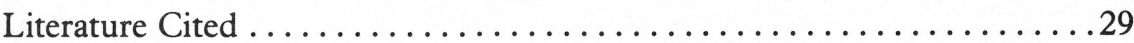

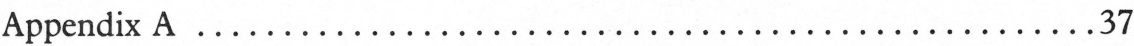

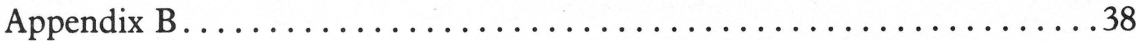




\section{ABSTRACT}

Wood industries produce large volumes of residues which must be utılized, marketed, or disposed of. Environmental regulations are restricting the traditional disposal methods of open burning or uncontrolled dumping, raising concern over future wood residue disposal costs. An alternative use of wood residues is for energy production. Much attention has been given to wood energy systems in recent years because of increasing costs of fossil fuels and concern over the environmental effects of their use. This report, based on an extensive literature review, summarizes recent developments in wood energy technologies. Major subjects include basic considerations in wood combustion, fuel handling and preparation, wood-fired furnaces, co-firing wood and coal, cogeneration of process steam and electricity, wood gasification, and methanol synthesis. General observations are made on the economics of wood energy systems, but in-depth treatment of the relative economics of wood energy systems versus alternative systems is deferred to the second volume of this bulletin. 


\section{INTRODUCTION}

West Virginia's wood products industry produces substantial amounts of wood residues from its manufacturing activities-over 1.4 million tons per year by latest estimates. About $20 \%$ of this is not sold or used in any manner. Current and pending state environmental regulations prohibit open burning and uncontrolled dumping, which are the traditional methods of disposal of residues.

Mills must remove their residues in order to continue operating. The residues can be either used in-house, sold if a customer is available, or taken to a sanitary landfill, which is very expensive. If mills cannot dispose of their residue, or cannot do so economically, they will have to close. Many jobs could be lost, both directly from the forest products industry and indirectly from supporting businesses.

One option for dealing with wood residues is to increase their use as an energy resource, or fuel. Some larger wood products mills in West Virginia already do this, and there are limited markets for wood residue fuel outside the industry. However, these markets use only some of the available residues.

Increased use of wood residues for energy production could have several benefits for the industry and the state. For the industry, increasingly costly disposal methods could be avoided. Residues used in-house could substitute for costly fossil fuels. If outside wood fuel markets can be developed, wood residue sales could potentially become a direct revenue source. For the state, economically and environmentally sound ways of using wood residues would allow the recent growth in the state's wood industry to continue. Conversely, if wood residues must be disposed of at increasing cost, further development of the industry in the state will be stifled.

For many decades, abundant and dependable supplies of inexpensive fossil fuels have prompted a shift away from the use of wood as an energy resource. Within the last two decades, a combination of economic and political factors have worked to greatly increase the direct cost of fossil fuels, and to raise concerns about their future availability. Moreover, concerns over the environmental effects of unrestricted fossil fuel use have led to governmental regulations which can make fossil fuel energy even more costly. Given these developments, there has been a renewed interest in the use of wood as an energy resource. Much research on wood-fueled energy systems has been conducted and a number of new prototype and commercial wood energy systems have been operated in recent years.

The objectives of this research were to: (1) review the literature on recent developments in wood energy systems and summarize the major findings concerning technologies for using wood residues as an energy resource; (2) analyze the economics of utilizing these technologies in relation to alternative 
energy resources and technologies; (3) define potential energy-related markets for West Virginia wood residues; and (4) determine the effect of governmental regulations on the potential use of feasible wood energy technologies and suggest regulatory changes to encourage use of these technologies.

This report includes findings relative to objective (1), above. Findings relative to the other objectives will constitute Volume Two of this bulletin: "Wood Residues as an Energy Resource-Part II: Economics and Marketing." 


\section{WOOD RESIDUES AS AN \\ ENERGY RESOURCE \\ PART I: A REVIEW OF TECHNOLOGIES}

David W. Patterson and Gary W. Zinn

\section{WOOD RESIDUES AND THEIR USES}

In the process of turning trees into logs, logs into lumber, and lumber into finished products, residues are generated (Moore 1975). It is a hardwood industry generalization that half of the wood in a tree is left in the forest as logging residue, half of the log becomes mill residue, and half of the lumber becomes machining residue (Figure 1). About one eighth of the wood in a tree is used in the major final product. Patterson and Brock (1986) found, at the larger sawmills in West Virginia, that for every 1,000 board feet ( $1 \mathrm{MBF}$ ) of lumber sawn, 1.31 ton of chips, 0.67 ton of sawdust, and 0.66 tons of bark were generated. Over half of the green log weight coming into a mill leaves as residue. Flanigan (1980) stated that approximately $50 \%$ of the log volume entering Missouri sawmills becomes residue.

A residue survey conducted during 1986 (Patterson 1988) indicated that $1,415,632$ tons of residues were produced at West Virginia forest products mills. Approximately 1,350,000 tons, or $95.4 \%$ of these residues, were green sawmill residues. Secondary processors accounted for the remaining $4.6 \%$. Only $6.1 \%$ of the residues were used in-house for energy. About $19.9 \%$ of the total is either given away or dumped because it cannot be sold or used in-house. The residues that are disposed of or sold without a contract total $67.3 \%$ or about 950,000 tons per year. Most of these residues should be available for industrial development if the price and location are competitive. Green sawdust appears to be the main residue problem.

Residues can be sold, burned, landfilled, or used in-house as fuel. The burning and landfilling options have been all but eliminated in some areas by air and water pollution regulations (Moore 1975).

The West Virginia Department of Natural Resources (1988) Division of Water Quality promulgated some "best management practices" for handling untreated wood waste. The main concern behind these practices is the control of the leachate coming from the piles of residues. Rain and surface water may pick up water-soluble extractives or chemical by-products of wood decomposition. It is possible that in the future all piles of woody material will have to be covered and kept from immediate contact with the ground or ground water. 


\section{Wood Residue Generation In $\%$ of whole tree}

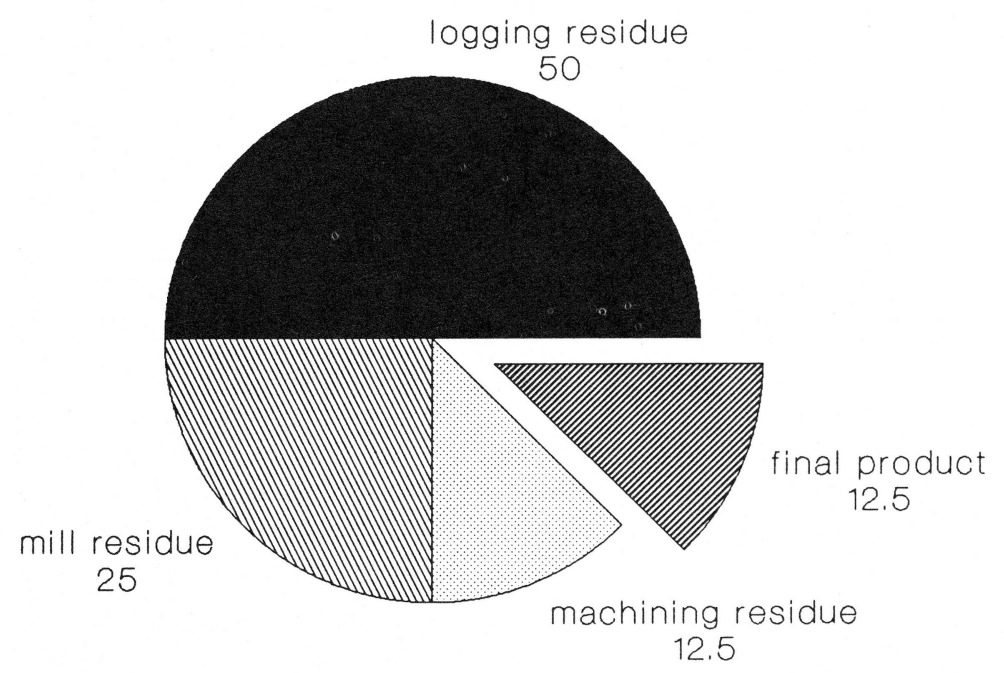

Figure 1. Generalized relationship between residue and product volumes in converting trees to final product.

The West Virginia Air Pollution Control Commission (1974) eliminated open air burning and tepee burning of wood residues. Their reasoning was that the chemical by-products and particulate emission resulting from uncontrolled combustion reduce air quality.

Uses of residues are dependent upon the type of residue. Moore (1975) found that most bark residue was used for plant fuel, while Patterson (1988) found in West Virginia most of the bark was used for mulch; some mixed with sawdust was used for fuel or charcoal manufacture. Moore and Patterson found a very limited use for sawdust, with the most use being for fuel. Moore found that the solid scrap (slabs, edgings, and end trim) was sold as chips to pulpmills. Patterson found the same at larger West Virginia sawmills, but at the smaller mills the solid scrap was piled on the ground or sold to individuals as firewood. Moore stated that planer shavings were used in board products. Patterson found the planer shavings were used for fuel or animal bedding or were buried in landfills.

In the United States, the end use of most timber is for fuel and not lumber, paper, or other products. The use of wood residues and energy conservation measures have enabled the pulp and paper industry to reduce its fuel oil consumption by $50 \%$ (Koning and Skog 1987). Goetzl and Tatum (1983) 
reported that $73 \%$ of the energy used by 17 companies was generated from hogged fuel, bark, and other wood residues. These 17 companies owned about 500 mills nationwide an contributed approximately $30 \%$ of the lumber production and $60 \%$ of the plywood and composite board production in the United States. There is a potential for the secondary wood products industries to be energy self-sufficient and sell quantities of residues to other industries (Duke and Keenan 1983). If all of the wood residues in the South were used for energy, about $3 \%$ of the nation's energy needs could be met (Curtis 1978a). Ellis (1975) forecasted that for the next 10 to 25 years, the principal users of wood and bark fuels would be forest products industries. Recently, many non-forest products industries such as educational institutions, textiles, brick, and foodstuffs industries, as well as hospitals and public buildings, have started using wood for energy (Young and Ostermeier 1987, Govett and Meimban 1989).

Because of a limited electricity supply and an adequate low quality timber supply, 11 small power plants are scheduled to go on-line in New Hampshire to produce electricity from wood fuel. A documentary has been produced to educate and inform the public about the wood-energy cycle so as to calm the fears that the timber resource will be depleted (Jordan 1989).

The competitiveness of wood residues against other fuels depends on a number of interrelated factors. These include: the heat value of alternative fuels; boiler efficiencies and energy system capital and operating costs; the scale of the system (total amount of energy required); whether wood residues to be used are generated in-house (or very near by), or whether they must be procured from a large supply area; and whether a revenue-producing market exists for the residues.

The heat values of various common fuels are well documented. Curtis (1978b) developed a Fuel Value Calculator which shows, in dollars, the fuel value of wood residues at several moisture contents and various other fuels based only on their Btu content. That value does not include handling, storage, maintenance, amortization, or other costs associated with a given type of fuel. For example, if natural gas were selling for $\$ 3.00$ per 1,000 cubic feet, the fuel value for green sawdust ( $60 \%$ moisture content DB) would be $\$ 29.87$ per ton.

Because of economic and political developments within the last two decades, fossil fuels-particularly natural gas and oil-have attained much higher market prices for equivalent heat values than wood residues, and this trend is expected to continue. Armstrong and Brock (1988), using local prices, found that to dry $1 \mathrm{MBF}$ of lumber required either $\$ 22.23$ worth of gas, $\$ 33.11$ worth of oil, or $\$ 8.46$ worth of coal. Sawdust and bark had a high delivered price of $\$ 10.00$ per ton or a high mill site price of $\$ 1.50$ per ton resulting in costs of $\$ 9.70$ or $\$ 1.46$ to dry the $1 \mathrm{MBF}$ of lumber. Mares (1981) predicted that the natural gas production will not meet the demand. The gap could reach 7 trillion cubic 
feet per year by 1990 and 13 trillion by the year 2000 . Wood can also compete against fuel oil because one ton of wood chips yields as much energy as 115 gallons of fuel oil (Anonymous 1979). This does not mean that wood is a desirable substitute, financially, for all fossil fuels in all circumstances (Tillman 1981). In particular, wood is generally a much more competitive fuel for small-scale energy systems than for large systems because wood residues mostly exist in small, scattered supplies. Gathering wood for a large-scale fuel system would incur significant transportation costs, increasing the price of material which otherwise may have little or no market value. Conversely, small energy systems which can use on-site or nearby supplies of wood residues would incur only modest wood fuel purchase and transportation costs. Of course, a large in-house or nearby residue supply can support a large energy system, as is the case at most large wood products mills.

Moore (1975) asserted that, even at their highest values, the sale of most residues does not come close to providing the return that is available if used in-house to replace fossil fuels. Mason (1975) stated that the value of a residue should be determined by: (1) the profit potential of using it for another product, (2) the net difference in value of what it will replace as a fuel, or (3) the cost of disposal.

\section{WOOD COMBUSTION}

"Wood is not an ideal fuel. It is solid, of modest heat content, frequently wet, and bulky to transport. Wood fuels have certain advantages, however. Wood is a renewable resource" (Jamison 1979). Wood, because of its value, renewability, clean burning characteristics, and availability, is an extremely viable source of energy when compared to other non-fossil fuel alternatives.

\section{Fuel Value of Wood}

Wood contains water. The gross heating value that is available from a given wood fuel is determined by its moisture content. Moisture content is expressed in two ways. Some researchers, particularly engineers and chemists, use the wet basis (WB) while others, including wood scientists, use the dry basis (DB). With the wet basis, the moisture content is calculated by dividing the weight of the water by the total weight including the weight of wood and water. With the dry basis, moisture content is calculated by dividing the weight of the water by dry weight of the wood (Westphal 1983). "The use of the dry basis has advantages in an analysis of wood fuels, although it is not commonly used in this application. In calculations based upon the dry basis moisture content, the total amount of fuel does not change as the fuel is dried, only the available heat per pound changes. When using the wet basis moisture content for analysis, both the amount of fuel and the available heat per pound change as the fuel is dried." 
(Haygreen 1981) Some examples of the differences in the basis are: $33 \%$ $\mathrm{WB}=150 \% \mathrm{DB} ; 50 \% \mathrm{WB}=100 \% \mathrm{DB}$; and $67 \% \mathrm{WB}=200 \% \mathrm{DB}$ (Figure 2).

The gross heating value of oven dry wood is approximately 8,600 Btu per pound (Curtis 1978a, Lin 1981, Reinke 1961), although the value for some resinous conifers may be 9,150 Btu per pound (Reinke 1961). Corder (1975) reported ranges of values: 8,000-8,500 for non-resinous wood and 8,600-9,700 for resinous wood. Manwiller (undated) found that hardwood trees growing on southern pine sites had a heating value ranging from 6,840 to 8,183 Btu per oven dry pound.

Moisture can affect the amount of useable heat in two ways. First, a pound of wet wood is comprised of less than a pound of wood and the remainder is water, which does not burn. For example, a pound of wet wood with a moisture content of $50 \% \mathrm{WB}(100 \% \mathrm{DB})$ would be a half pound of wood and a half pound of water. Therefore, the gross heating value of this wet wood would be the same as for a half pound of oven dry wood-4,300 Btu (Figure 2). Secondly, during the combustion of wood, hydrogen combines with oxygen to form water. Wood has more hydrogen and oxygen than coal or oil; therefore, wood has 3\% less of its total potential heat available than does coal or oil (Reinke 1961).

Wood-fired boilers operate at about $80 \%$ efficiency with oven dry wood; therefore, $8,600 \mathrm{Btu}$ of gross heat provides approximately 6,900 Btu of useable heat (Curtis 1978a, Lin 1981). Boilers operate at lower efficiency with wetter wood, and provide only about $67 \%$ of gross heat with wood at $50 \% \mathrm{WB}$ or $100 \%$ DB (Figure 2). There is a theoretical blackout point (approximately 67\% WB-200\% DB) at which wood will not support combustion (Bulpitt and Walsh 1982, Lin 1981, Miller and Hansen 1951).

There are three phases to the combustion of wood (Reinke 1961). First, the free water is removed by evaporation or vaporization, depending on whether the temperature is below or above boiling. Secondly, chemical breakdown of the wood takes place, producing gas, volatile liquids, and charcoal. The gas and liquids are burned, producing mainly carbon dioxide and water. The third phase consists of the charcoal being burned to produce carbon dioxide. The distillation of the wood as well as the vaporization of the water (present and produced) absorbs heat, which reduces the amount of useable heat available.

Bark generally has a higher Btu value than wood. Corder (1975) reported ranges of 7,400-9,800 Btu per pound for non-resinous species and 8,800-10,800 for resinous species. Manwiller (undated) found that hardwood bark had a lower Btu value than the wood (7,593 for bark versus 7,827 for wood). The effects of moisture content on bark combustion are similar to those found with wood (Tillman 1979). 


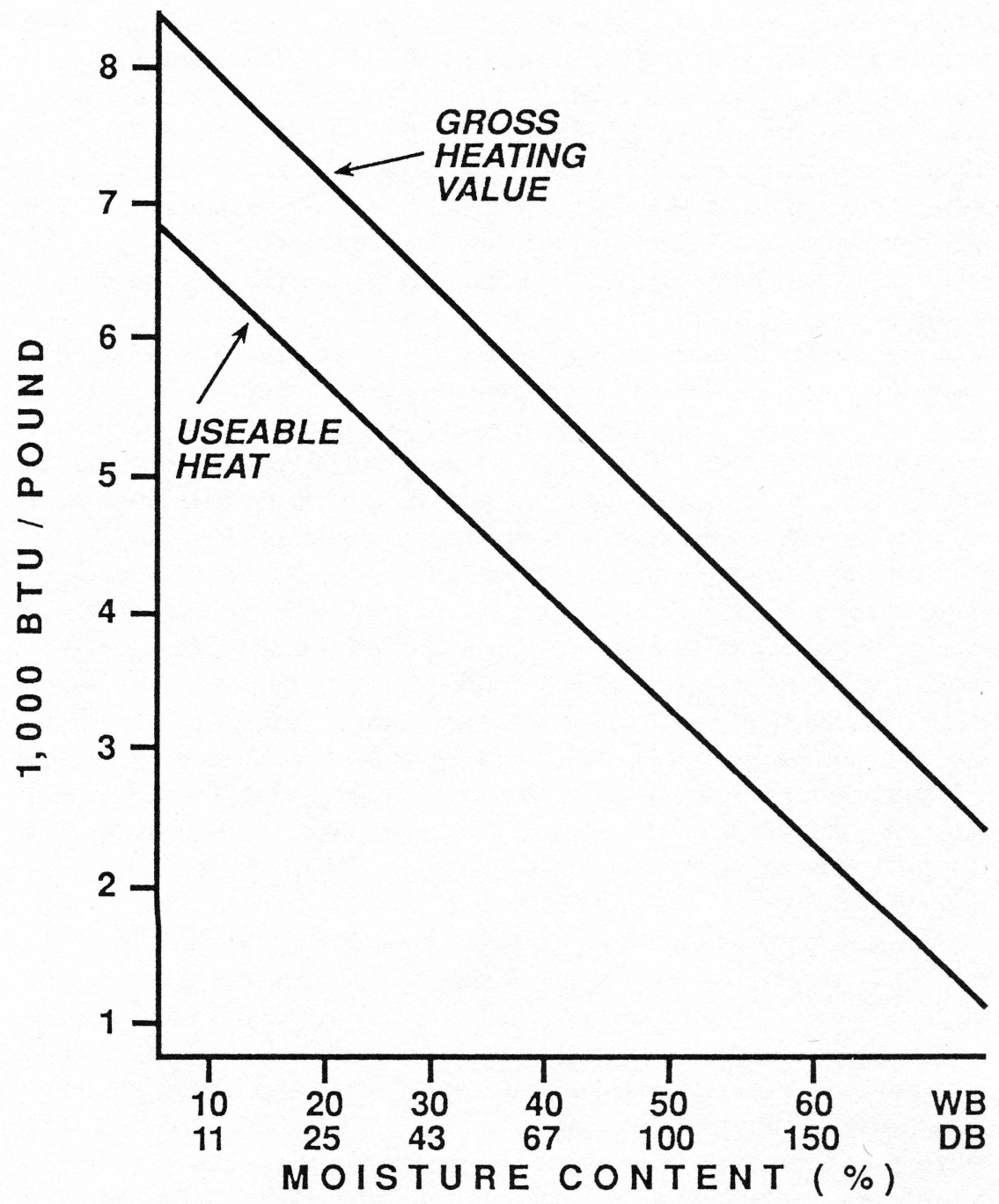

Figure 2. Generalized relationship between heating value and wood residue moisture content expressed as wet basis (WB) and dry basis (DB).

\section{By-products of Combustion}

Proximate analysis is conducted on a fuel to determine what portion of it is volatile, fixed carbon, or ash. The combined information from four articles (Corder 1975, Junge 1975, Villesvik and Tillman 1983, Helmer et al. 1988) is shown in Table 1. Data from seven species of wood, eleven species of bark, and two types of coal are included. Cedar is included in both the wood and bark data 
and its values are noticeably different from other species. The volatile component of wood is higher than that for bark. Both wood and bark have a volatile component three to four times higher than that of coal. The ash content of bark is four times higher than that of wood. The ash content of coal is more than 20 times higher than that of wood. The information from the proximate analysis is needed so that the proper equipment design and burning conditions can be developed to insure maximum heat recovery.

Table 1.

Proximate analyses of wood, bark, and coal. Percent of oven dry weight.

\begin{tabular}{lrrrrrrrr}
\hline & \multicolumn{2}{c}{ WOOD } & & \multicolumn{2}{c}{ BARK } & & \multicolumn{2}{c}{ COAL } \\
\cline { 2 - 3 } \cline { 8 - 9 } \cline { 8 - 9 } & mean & range & & mean & range & & mean & range \\
\hline Volatile & 84.2 & $77.0-87.0$ & & 73.6 & $65.8-86.7$ & & 26.3 & $17.7-34.9$ \\
Fixed Carbon & 15.3 & $12.8-21.0$ & & 24.6 & $13.1-33.8$ & & 64.4 & $56.9-71.8$ \\
Ash & 0.4 & $0.1-2.0$ & & 1.8 & $0.2-5.2$ & & 9.3 & $8.2-10.4$ \\
\hline
\end{tabular}

Sources: Corder (1975), Junge (1975), Villesvik and Tillman (1983), and Helmer et al. (1988).

Ultimate analysis is conducted on a fuel to determine what elements are present and in what proportions. The elements of major concern are hydrogen, carbon, oxygen, nitrogen, and sulfur. This information aids in determining the air flows needed for efficient combustion and the pollution control equipment required to meet air quality standards. Table 2 includes information from seven articles on the ultimate analysis of wood, bark, and five types of coal (Corder 1975, Junge 1975, Curtis 1978a, Doty et al. 1979, Flanigan 1980, Sarles and Rutherfoord 1982, Villesvik and Tillman 1983). Coal is about $75 \%$ carbon while wood and bark are only about $50 \%$. Also, coal is less than $10 \%$ oxygen while wood and bark are about $40 \%$. Many species of wood have no detectable sulfur (oak seems to have the highest levels for wood and bark) while many types of coal have a sulfur problem. The nitrogen content of wood and bark is less than that of coal and it usually is in such a chemical makeup that it does not combine with oxygen to become an air quality problem.

One of the obvious products of combustion is ash. Table 1 shows that $0.4 \%$ of oven dry wood, $1.8 \%$ of oven dry bark, and $9.3 \%$ of coal becomes ash when burned. A study on green bark by Villesvik and Tillman (1983) indicated 17.3 pounds of ash per ton of loblolly pine bark, 51.9 pounds per ton of Douglas-fir bark, 63.9 pounds per ton of oak bark, and 245.1 pounds of ash per ton of coal. Lin (1982) found 201 pounds of ash produced from 45 tons of green chips combusted in a 50-hour period. The ash contained primarily calcium, sodium, magnesium, and potassium. 
Table 2.

Ultimate analyses of wood, bark, and coal. Percent of oven dry weight.

\begin{tabular}{lcccccccc}
\hline & \multicolumn{2}{c}{ WOOD } & & \multicolumn{2}{c}{ BARK } & & \multicolumn{2}{c}{ COAL } \\
\cline { 2 - 3 } \cline { 8 - 9 } \cline { 7 - 8 } & mean & range & & mean & range & & mean & range \\
\hline Hydrogen & 5.9 & $5.1-6.3$ & & 5.6 & $5.4-6.0$ & & 4.8 & $4.2-5.2$ \\
Carbon & 51.5 & $50.2-52.0$ & & 52.7 & $49.8-56.4$ & & 72.8 & $67.7-80.0$ \\
Oxygen & 41.5 & $40.5-43.0$ & & 38.9 & $37.6-39.4$ & & 7.2 & $2.1-11.0$ \\
Nitrogen & 0.4 & $0.1-1.0$ & & 0.1 & $0.1-0.2$ & & 1.3 & $1.0-1.6$ \\
Sulfur & 0.04 & $0.0-0.15$ & & 0.03 & $0.0-0.1$ & & 2.6 & $1.7-3.3$ \\
\hline
\end{tabular}

Sources: Corder (1975), Junge (1975), Curtis (1978a), Doty et al. (1979), Flanigan (1980), Sarles and Rutherfoord (1982), and Villesvik and Tillman (1983).

The U.S. Department of Energy (1981) stated that wood ash disposal is a potential concern, but it is apparently not a great problem since the ash can be used as a soil amendment or can be disposed of in a sanitary landfill. Lazare and Campbell (1989) found that when wood ash was added to the soil at the $2 \%$ level, vegetative growth increased significantly. They concluded that it would be more environmentally sound and cheaper to apply the ash to the land than to dispose of it in landfills.

Wood ash must be handled so as not to harm water quality. Rainwater can collect beneath the ash stored in open outdoor storage piles, and the acidic water may then be flushed out after heavy rains (Technology Applications Laboratory 1984).

Other products of combustion go up the "smoke" stack. Sarles and Rutherfoord (1982) stated, "what we see as smoke is mostly unburned carbon which settles out as soot." In their study of green bark fuels, Villesvik and Tillman (1983) found that the stack gas averaged $12.8 \%$ carbon dioxide, $24.8 \%$ water vapor, $59.7 \%$ nitrogen, and $2.6 \%$ oxygen. Only the oak bark showed evidence of sulfur dioxide (132 parts per million). The value for nitrogen appears high until one remembers that normal air (infeed air) is approximately $79 \%$ nitrogen. Table 3 shows the comparison of the stack gases from green bark and bituminous coal.

Both gaseous and particulate pollutants can be emitted from the stack. The gaseous pollutants are carbon monoxide, sulfur dioxide, oxides of nitrogen $\left(\mathrm{NO}_{\mathrm{x}}\right.$ ), and unburned hydrocarbons (Junge 1975, Villesvik and Tillman 1983). The oxides of nitrogen are mainly from the nitrogen compounds in the fuel rather than the nitrogen in the air, and the amount of oxides produced is influenced by the flame temperature and residence time in the firebox (Helmer et al. 1988). 
Particulate pollutants include flyash, unburned carbon, condensed droplets of liquid hydrocarbons, and metallic salts. The regulatory definition of particulate is somewhat different from the normal definition. Under air quality regulations, any material that exists either as a solid or liquid under standard conditions of 29.92 inches of mercury and 70 degrees $F$ is a particulate. Some stack gases would be classified as particulates because they would condense at the lower temperature. Flyash particles range in diameter from 1 micron to more than 100 microns with an average of 15 microns. As a comparison, the "period" made by a typical typewriter is 850 microns in diameter (Junge 1975).

Table 3.

The stack gas products of combustion for green bark and bituminous coal.

\begin{tabular}{lccccc}
\hline Fuel & $\begin{array}{c}\mathrm{CO}_{2} \\
\%\end{array}$ & $\begin{array}{c}\mathrm{H}_{2} \mathrm{O} \\
\%\end{array}$ & $\begin{array}{c}\mathrm{N}_{2} \\
\%\end{array}$ & $\begin{array}{l}\mathrm{O}_{2} \\
\%\end{array}$ & $\begin{array}{c}\mathrm{SO}_{2} \\
\mathrm{ppm}\end{array}$ \\
\hline Green Bark & 12.8 & 24.8 & 59.7 & 2.6 & 44 \\
Coal & 14.6 & 5.0 & 76.9 & 3.4 & 1275 \\
\hline
\end{tabular}

Source: Villesvik and Tillman (1983).

$\star \star$ oak had $132 \mathrm{ppm}$, the others had 0 .

\section{Pollution Control Devices}

Numerous systems in use today very effectively remove pollutants from stack gases. Modern wood energy systems are relatively clean-burning. One type, called scrubbers, works on the principle of trapping small particles on the surfaces of large particles. Reese (1975) reported on a dry scrubber system which used a thick bed of pea-gravel-type media that appeared to be quite effective for wood-fired boilers. Wet scrubbers use liquid droplets as the large particles. These wet scrubbers are usually 95 to $98 \%$ efficient. There are two problem areas with wet scrubbers. First, the solids must be separated from the liquid and both disposed of in an environmentally sound manner. Secondly, wet scrubbers may generate a water vapor plume that uninformed citizens may consider as a pollutant.

A second type of pollution control system is called a cyclone. This system works on the principle that if the gases are forced into a circular pattern, centrifugal force will separate the particles from the carrier gases. The smaller the diameter of the cyclone, the higher its efficiency. A multi-cyclone is a system of many small cyclones used in parallel instead of one large cyclone. There are many factors that affect the efficiency of a cyclone system, and there is always a possibility of a leak which could cause re-introduction of the particles into the gas stream. 
Baghouse filters are not used extensively with wood-fired systems. The larger particles of flyash from wood fires tend to clog the filters more than coal flyash particles. Also, wood fires tend to have more airborne burning carbon, which could pose a fire hazard for the baghouse. To remove the particles from the filters so that the gases can pass through, the filters must be flexed and shrunk constantly. This reduces the life of the filters, resulting in a high maintenance cost. If properly maintained, the baghouse filters are $99 \%$ efficient in removing flyash and unburned carbon.

There has been limited use of electrostatic precipitators in wood-fired systems. They are a high capital cost item. Also, many factors cause a low collection efficiency, especially the low electrical resistivity of flyash and unburned carbon.

\section{FUEL HANDLING AND PREPARATION}

As quoted earlier, "Wood is not an ideal fuel. It is solid, of modest heat content, frequently wet, and bulky to transport" (Jamison 1979). Jamison further stated that wood fuel could be upgraded by drying, screening, grinding, washing, and densifying or pelletizing. "The handling and storage of wood fuels involves a number of problems and considerations that are not commonly found in coal handling systems (Bulpitt and Walsh 1982)." Transportation costs were felt to be a constraint on wood fuel use by $65 \%$ of the companies surveyed by Ostermeier et al. (1988). Young et al. (1988) reported that the trucking costs to haul wood chips ranged from $\$ 0.139$ per ton-mile for 1 to 20 miles to $\$ 0.074$ per ton-mile for over 60 miles hauling distance. The average hauling distance for nonforest products firms using wood fuel was 27 miles (Young and Ostermeier 1987). Harris (1982) reported that hauling costs may amount to more than $75 \%$ of the total delivered cost of wood fuel.

\section{Drying}

One way to reduce transportation costs and improve energy conversion efficiency is to reduce the moisture content of the wood residue (Callas 1988). For each pound of water removed from the residue, the heating value increases by 1,100 to 1,250 Btu (Haygreen 1981, Haygreen 1982, Harris 1989). Other benefits obtained by reducing the moisture content are: reduced storage costs; reduced biochemical deterioration during storage; increased efficiency and capacity of the boiler; and a reduction in the volume of stack gases (Haygreen 1981, Steklenski et al. 1989).

The conventional method for drying wood particles is the rotary drier in which the particles are tumbled through a revolving drum with hightemperature air blowing through them. These driers can dry wood to any moisture content desired. The main disadvantage of the rotary drier is that it requires 1,700 to $1,900 \mathrm{Btu}$ to remove each pound of water. This is significantly 
higher than the increase in heating value realized by the removal of the water (Haygreen 1982, Harris 1989).

The capital cost of the drier is significant, and if fuel has to be used to heat the air, the economic advantage of using wood residues as a fuel may be lost. On the other hand, if "free" heat can be used to heat the air, the use of dried residues can become quite advantageous. For example, if the exhaust stack gases were used to dry the wood fuel, the drying would be accomplished with heat that would normally be wasted by venting into the atmosphere. One potential problem exists: a fire can start in the drier if glowing carbon is present in the exhaust gases.

Harris (1989) dried southern pine sawdust and chips using accelerated ambient air. By blowing room air through the residue, he was able to lower the moisture content from $120 \%$ to $30 \%$ dry basis. The energy used to run the system while drying sawdust was equivalent to $16 \mathrm{Btu}$ per pound of water removed; for chips, it was 43 Btu per pound of water. Ambient air with a temperature of 94 degrees $\mathrm{F}$ removed considerably more water than ambient air at 78 degrees $\mathrm{F}$.

Haygreen $(1981,1982)$ investigated the removal of water from wood fuel chips by compression. He was later joined by other researchers and the project was expanded to include baling the dewatered chips (Liu and Haygreen 1985, Callas 1988, Steklenski et al. 1989). Most current compression dewatering systems utilize pinch rollers to force the water out of the wood. However, water tends to stay between the rollers and as the wood expands coming out of the rollers, the water is absorbed back into the wood. Rollers normally change the moisture content from $150 \%$ to $100 \%$ DB. Haygreen and associates used a ram to compress the residue at $2,000-4,000$ psi in a cylinder with water removal slits. After the compression cycle, the residue was forced into a baling chamber where wrappings were put around the residue to create $13 \times 13 \times 16$-inch bales. The moisture content was reduced from $100 \%$ to $50-70 \%$ DB.

In analyzing the variables affecting the compression drying rate, Liu and Haygreen (1985) found that initial moisture content had little effect on the final moisture content. Species and specific gravity strongly affected the final moisture content, and forces two to three times greater had to be applied to high specific gravity samples to reach the same moisture content as the low specific gravity samples. Most of the water is removed during the first two minutes of pressing. After 3-4 minutes water removal is negligible. Chip size was also a significant variable in determining final moisture content. In general, the researchers concluded that the energy increase in heating value was 70 times greater than the energy expended to compress the residue and remove the water. The waste water is a potential problem. The water needs to be analyzed to see if any chemicals present will cause it to be a costly disposal problem or a revenue source. 
It was also found that the medium and high density bales could withstand the rigors of stacking and handling. If stacked with air spaces in the interior of the stack, the bales continued to dry in a manner similar to solid wood. The moisture content for bales that were stacked for 98 days was $15 \% \mathrm{DB}$. There was a tendency for low density bales and bales that had dried below the fiber saturation point (shrinkage) to fall apart during handling.

\section{Residue Storage}

Where practical, residue storage should be covered by an open-sided building to keep it dry (Kallmeyer 1982). Storage facilities should be designed to permit easy removal of the fuel at the desired time (Bulpitt and Walsh 1982). Some air drying can take place in covered storage, but this is minimal and is not the main reason for the cover. Rain and snow can raise the moisture content of residues in uncovered piles to the blackout point (i.e., it will not burn) (Bulpitt and Walsh 1982).

White et al. (1983a, 1983b) found that within 2 to 4 months after outdoor piles were established, an outer saturated layer about 5 feet thick developed. The average maximum moisture content for this layer was 140 to $160 \% \mathrm{DB}$ for hardwood whole-tree chips and sawdust and 210 to $220 \%$ DB for hardwood bark. The interior of the chip piles became drier with time, but the interiors of the other piles continued to increase in moisture content throughout the year of storage. It was concluded that the outer layers of chips created a shingle effect which kept the rain from penetrating the pile. With the increase in moisture, there was a corresponding decrease in available energy in the residue. These losses in energy can be reduced by: limiting the storage cycle to less than 60 days, storing residues in chip form if possible to get the shingle effect, reducing the horizonal area of the pile, and increasing the height of the pile.

The height of the pile is important in that spontaneous combustion can take place in large residue piles, destroying the whole pile. White et al.(1983a, 1983b) used 15-foot piles and recommended that the height be increased. Bulpitt and Walsh (1982) recommended that bark not be piled higher than 15 feet. Others have recommended that the maximum height for chips is 50 feet and for hogged fuel is 30 to 40 feet (Nor'west-Pacific Corp. 1981). Pile temperature should be monitored. If the temperature becomes too high, pile size must be reduced.

To facilitate storing and conveying, sizing equipment should be placed first in the material flow. Large chunks of wood can be burned but they are difficult to store and convey. Therefore, it is necessary to hog the fuel down to manageable size. The removal of oversize pieces and debris such as metal or other refuse must be accomplished before the fuel enters the system, to prevent 
damage to the handling equipment. Effective combustion of wood residues is dependent upon uniform particle size (Cobb 1982, Kallmeyer 1982, Bulpitt and Walsh 1982).

Harris (1982) reported that some wood fuel users may have to deal with as many as 30 suppliers to obtain the volume of wood residues that they need. He stated that distribution yards were being set up to supply wood fuel to industrial users. These yards have facilities to weigh, unload, sort, store, and retrieve wood fuel. They handle the duties of procurement, billing, storage, and timely delivery of the fuel. Harris cautioned that only $10 \%$ of such businesses last for five years.

To encourage better utilization of wood residues in Missouri, the Missouri Forest Products Association formed the Missouri Forest Products Marketing Corporation (Freeman and Short i982). This corporation bought residues from the sawmills, concentrated them, and sold them to the large and medium wood fuel users. The purpose was to guarantee the availability of wood residues on a steady and long-range basis at stable and consistent prices for large and medium users. This corporation no longer exists, but it has been replaced by several private companies (Jones 1989).

\section{Densification}

Densification can be used to overcome some of the disadvantages that wood residues have as a fuel. Particularly, densification lowers transportation and storage costs. There has been considerable commercial experience with densification or pelletization of wood residues within the last two decades. Centers of activity have included the Lake States, Pacific Northwest, and southeastern Canada. The process consists of reducing wood residue material to approximately sawdust-sized particles, drying to $10-18 \%$ moisture content (DB), and then densifying the feedstock in an extruder. The resulting wood fuel "pellets" are generally $1 / 4$ or $3 / 8$-inch by $3 / 4$-inch in size, with bulk densities of 35-42 pounds per cubic foot. Alternative extruder designs can produce "briquettes" ( 3 inches by 3 to 12 inches) or "logs" ( 3.5 inches by 12 inches) of about 55 pounds per cubic foot density. (Callas and Haygreen 1987).

Wood pellets have been used as industrial and institutional fuel and in residential heating, while briquettes and logs have been sold mainly for residential use (Callas and Haygreen 1987, Folk et al. 1988).

At least four patented pelletizing processes are commercially available; these were described by Folk et al. (1988). Since wood pelletizing is a distinct manufacturing process, it requires capital investment in specialized equipment -e.g., $\$ 1.8$ million for a 100 ton per day plant (Callas and Haygreen 1987)and has specific operating costs as well. Callas and Haygreen (1987) cited a 1986 feasibility study which estimated pellet production costs at $\$ 40-\$ 42$ per ton. With distribution costs and profit margins added, a market price of $\$ 50$ per ton 
was estimated; this is some three times (or more) the typical price per ton of green wood residues (Callas and Haygreen 1987, Technology Applications Laboratory 1984).

The advantages of densified fuels are consistent product dimensions, easier handling and storage, and more efficient burning. Pelletizing makes a useable wood fuel of sawdust and fines which otherwise may be difficult to dispose of or to use. Both capital and operating costs for wood fuel handling equipment can be reduced since the uniform product allows storage, handling and combustion equipment to be designed to specific characteristics. Thermal efficiency is improved-pellets can be $15 \%$ higher in thermal efficiency than green wood (Technology Applications Laboratory 1984).

\section{Wood/Coal Densification}

Chen et al. (1989) investigated in the laboratory the possibility of making pellets with wood and bark residues combined with coal fines from tailing ponds. The idea was to make a pellet with a higher Btu value and a low sulfur content. They used aspen and oak wood and bark. The results showed that when oak was used, a higher ram pressure was required, the moisture content after manufacture was higher, and the pellets were less durable. As the amount of bark was increased in the pellets, the required ram pressure decreased, the moisture content after manufacture increased, and the pellets were more durable. As the amount of coal fines in the pellets increased, the required ram pressure increased, pellet density increased, moisture content after manufacture decreased, pellet hygroscopicity decreased, and the pellets were less durable. Coal fines by themselves cannot be compressed into pellets; they need a binder. Co-firing of wood and coal will be addressed in another section.

\section{FURNACES}

There are several types of furnaces used for the combustion of wood residues. Some take the residues in any shape or form while others require a specific moisture content and/or particle size.

\section{Dutch Oven}

One of the oldest types of furnace to be used by the forest products industry is the Dutch oven. This type of furnace can take a wide variety of fuels, including very wet ones. The fuel is usually shoveled or conveyed into a pile in the firebox, where it burns. Because of this burning pile, Dutch oven furnaces are very poor at responding to wide fluctuations in steam demands (Cobb 1982). Dutch oven furnaces have two serious faults (Host and Lowery 1970). First, unless combustion is closely controlled, they are relatively inefficient in combustion and producing steam, particularly when the fuel is primarily bark. Second, 
because of this inefficiency, this type of furnace releases relatively large volumes of pollutants into the air.

The authors have had discussions with several industry personnel at various meetings in West Virginia. From these discussions, it was found that the boilers having the most trouble meeting air pollution standards were the Dutch oven type. One company shut down its Dutch oven boilers and went to an alternative processing technology that did not require steam.

\section{Suspension Furnaces}

A suspension furnace burns the wood residues in suspension with a high volume of air. There is no need for a grate. This type of furnace requires dry material (less than $15 \% \mathrm{DB}$ ) that has been finely hogged or pulverized (Tardif 1979, Nor'west-Pacific Corp. 1981, Cobb 1982).

There are various types of suspension burners, but they can be classified mainly into three groups (Nelid 1979). The first group, the fuel/air mixer and igniter type, requires the finest and dryest fuel, and is usually used where sander dust is available. The second group, cyclonic, can use coarser and somewhat wetter fuel, but planer shavings or plywood trim must be hammer hogged. In this type, the fuel and air is introduced in such a manner that a flaming vortex is produced in the burner. The third type, the fuel/air mixer, igniter and vertical/cylindrical furnace type, can use the coarsest and wettest fuel, such as planer shavings and sawdust (without hogging), but not wet and mill run hog fuel.

In all cases, the fuel must be completely burned before leaving the furnace. The main considerations in choosing a suspension burner are the fuel moisture content, particle size, and the type of equipment the burner will be heating (Nelid 1979). Jasper and Koch (1975) reported on a type of suspension burner that would use green bark to direct-fire dry kilns for drying southern pine lumber, eliminating the need for a boiler.

Southworth (1979) reported on a boiler that combined a Dutch oven furnace at the bottom and a suspension burner above. The Dutch oven burned wet hogged fuel and supplied the base heat while the suspension burner utilized dry wood fines and sander dust to meet fluctuations in steam demand.

\section{Spreader Stoker}

The spreader stoker, in contrast to the pile burning of the Dutch oven, distributes the fuel evenly over a large grate area to ensure complete and efficient combustion (Jamison 1979). This fuel distribution can be either mechanical or pneumatic (Nor'west-Pacific Corp 1981).

The performance, efficiency, and convenience of spreader stoker furnaces vary depending on the type of grate utilized. Grates can be stationary-flat, stationary-inclined, dumping, or traveling. The stationary-flat grate is similar 
to the Dutch oven except that the fuel is evenly distributed. This grate must be hoed frequently to remove ash. The stationary-inclined grate furnaces use either steam, air, or the turbulence of the combustion chamber to move the fuel bed down the incline so that the ash falls off the lower edge. Occasional cleaning may be required. The dumping grate periodically tilts, dumping ash into the ash pit. The ash pit also acts as a plenum chamber for the underfire air. The traveling grate is a sprocket-driven endless belt that moves the fuel bed along until only ashes fall into the ash pit. Because the traveling grate is continually removing ash, the underfire air makes better contact with the burning fuel, resulting in better combustion efficiency. (Miller and Hansen 1951, Jamison 1979, Nor'west-Pacific Corp. 1981, Villesvik and Tillman 1983)

The traveling grate-spreader stoker combination provides good loadfollowing characteristics and a high combustion efficiency for a wide variety and mixture of fuels. Because the fuel must be burned before the ash drops into the ash pit, high moisture content fuels can be a problem. Coal produces a large volume of ash; therefore, the traveling grate is recommended over the other three types of grates for coal fuels.

\section{Fluidized Bed}

A fluidized bed combustor was developed in 1921 by Fritz Winkler (Smith 1985). Further interest and research occurred in the 1960s. Toth (1985) reported that in 1977 fluidized bed steam generators were available in this country.

The fluidized bed gets its name from the bed of inert material (e.g., sand, glass beads, or crushed limestone) with a stream of high pressure air flowing through it, giving the appearance of boiling water (Andrew 1979, Euchner 1987). The bed material is heated to a temperature of 1,500 to 1,800 degrees $F$. As the bed, air, and fuel are mixed, the air and fuel are in turn heated and rapid pyrolysis of the fuel takes place. The turbulence of the bed causes increased mixing of gases and exposure of new solid fuel surfaces, resulting in an increased rate of combustion. The bed has a very large heat reserve which prevents flameout with the periodic introduction of fuel with extremely high moisture content (Andrew 1979). Except for periods of start-up and severe disturbances, the fluidized bed combustor is smoke free and meets all opacity requirements (Keller 1975).

The fluidized bed combustor is a versatile system that can burn a variety of combustible wastes, either wet or dry, separately or together. Some of the wastes used as fuel are: high moisture peat, green bark, sawdust and other wood residues, spent sulfite liquid, oil, oil shale, waste oils, petroleum coke, high sulfur coal, anthracite culm, coal mine tailings, and sewage sludge (Keller 1975, Tardif 1979, Cobb 1982, Oakes 1982, Beisswenger et al. 1985, Smith 1985, Toth 1985, Berry 1989). 
In addition to eliminating opacity, fluidized bed combustors can reduce air pollution in two ways. The production of oxides of nitrogen is dependent on flame temperature. The temperatures at which most fluidized bed combustors operate (1,500-1,800 degrees F.) are low, and this effectively controls the formation of these oxides (Nor'west-Pacific Corp. 1981, Beisswenger et al. 1985, Euchner 1987).

If crushed limestone is used as the bed material, the emission of sulfur dioxide can be reduced up to 95\% (Andrew 1979, Beisswenger et al. 1985, Smith 1985, Toth 1985, Euchner 1987, Berry 1989). The limestone bed captures sulfur dioxide in a two-stage reaction. First, the limestone is calcined by the heat in the bed and produces calcium oxide. Then the calcium oxide combines with the sulfur dioxide to form calcium sulfate (gypsum). The first stage absorbs heat, while the second stage releases heat. These stages are thermally balanced in the 1,500-1,600 degree $F$ temperature range; the efficiency of sulfur dioxide removal drops off when the operation is out of this range. The combustion efficiency is also at its highest when sulfur dioxide removal is at its optimum (Smith 1985).

The fluidized bed combustor has two main advantages: it removes sulfur dioxide and it is a good combustor for co-firing wood residues with fossil fuels. It has some disadvantages also. First, the initial cost is higher than that of other types of combustors and the power cost to supply high pressure air increases operating costs (Nor'west-Pacific Corp. 1981). Another problem area is that the combustor needs numerous feed points. It was recommended that there be one feed point for each 10 square feet of bed area (Oakes 1982).

The cyclonic burners, traveling grate-spreader stoker, and fluidized bed furnaces are very successful technologies for combusting wood residues and meeting required standaras. They are considered "tried and true."

\section{CO-FIRING WOOD AND COAL}

Co-firing wood residues with coal has gained acceptance in various industrial sectors. According to Villesvik and Tillman (1983), "the practice of co-firing dissimilar solid fuels has many potential advantages, including improved boiler performance and improved system economics. However it is not simply a matter of stuffing the two fuels into the firebox. Rather, it requires careful consideration of: 1) the fuels themselves; 2) how they burn; and 3) how their combustion characteristics influence boiler design and operation."

Pulp and paper mills require large volumes of steam for their processing. To produce steam, in turn, requires large amounts of energy. Some mills do not produce sufficient residues to meet their energy requirements; therefore, they have switched to boilers that will accept multiple fuels (Ramsdell and Zawistowski 1985, Vosler 1985, Petchul 1988, Berry 1989). Two mills in New 
England have found that they can use northern wood residues and coal from West Virginia and Kentucky, and still meet pollution standards (Ramsdell and Zawistowski 1985, Berry 1989). Vosler (1985) found that blends of hogged wood residues with $13 \%$ coal or $5 \%$ rubber (from old tires) by weight did not significantly increase particulate or sulfur dioxide emissions.

For installations in other parts of the industrial sector, "the option of co-firing coal with a clean fuel like wood is a viable near-term solution to reducing sulfur dioxide and oxides of nitrogen emissions," (Helmer et al. 1988). The use of biomass fuels (e.g., wood) as alternatives to fossil fuels (e.g., high sulfur coal) can reduce sulfur emissions to the atmosphere and acid deposition (Zerbe 1989). Villesvik and Tillman (1983) pointed out that there is less fuel nitrogen in wood than in coal.

In a study reported by Doty et al. (1979) and Flanigan (1980), three fuel blends (based on volumes) were tested: (1) pure coal, (2) 1 to 1 wood to coal, and (3) 2 to 1 wood to coal. The results demonstrated a noticeable decrease in sulfur dioxide emissions with increasing wood content. There was no relationship established for emissions of oxides of nitrogen. It was pointed out that this emission is a function of flame temperature, residence time, and percent excess air, which were not study variables. Particulate emissions were not altered with wood added to the blend, but total hydrocarbon emissions increased as wood content increased.

In a study reported by Helmer et al. (1988), green oak sawdusî was added to coal. Tests were made at ratios of wood mass to total mass $0,25,50,75$, and $100 \%$. The results of the study indicated a slight reduction of sulfur dioxide emissions beyond that which was expected from the dilution of the fuel with wood. While investigating the bottom solids, it was found that when $50 \%$ wood was used, the capture of sulfur dioxide increased by $5 \%$ and when $75 \%$ wood was used, the capture increased by $8 \%$. It was concluded that their burner, with a fuel of $80 \%$ wood, would meet EPA new combustion source standards for sulfur dioxide emissions.

Doty et al. and Flanigan also reported that their traveling grate furnace was capable of burning a wood-coal mix with only slight modifications. The boiler efficiency was not significantly affected and the performance factor tended to decrease only slightly. Boiler response was affected; it was not able to follow steam load swings as well as with all-coal fuel.

Coal requires most of its air as underfire (i.e., below the grate) air because of its high fixed carbon component. Wood, with its high volatile component, requires most of its air as overfire air so as to ensure complete combustion of the gases given off. Reported values for overfire air for wood range from 55 to $80 \%$ (Reineke 1961, Junge 1975, Viliesvik and Tillman 1983). Helmer et al. (1988) found that 40 to $50 \%$ underfire air was a good compromise for mixed wood and coal fuels. 
Because wood burns mostly in the gas phase, the firebox of a traveling grate furnace must be taller and more slender for wood and shorter with more grate area for coal (Villesvik and Tillman 1983). In burning mixed fuels, a compromise must be reached. Usually the boiler is either volume or grate limited. Beisswenger et al. (1985) found that in their fluidized bed unit, $60 \%$ of the heat input was carried into the convective pass while burning wood, while with coal only $40 \%$ of the heat input was carried into the convective pass.

One potential problem in burning wood in a coal-fired installation is that wood flyash has larger particles than coal flyash. If a baghouse is used for the pollution control device, the wood flyash could possibly clog the filters quickly (Miller and Hansen 1951).

\section{COGENERATION}

Cogeneration is defined as the production of electricity and process steam with the same energy system (Brock et al. 1987), or the generation of mechanical power and thermal energy from the same primary energy source (Euchner 1987).

The U.S. Department of Energy (1981) stated "The use of wood waste in cogeneration, as forecast, could have a positive impact (on the environment) because it would replace the use of other fuels and electricity." In Wood and Wood Products (Anonymous 1979) it was stated that the most practical fuel source for cogeneration is wood.

Most cogeneration facilities are installed on the assumption that the process steam or thermal energy is needed and that steam will be produced anyway. In other words, the electrical or mechanical unit is added on to the process steam unit. Most of the energy required is used to change water at boiling to steam at boiling-i.e., state change energy (Figure 3). Once the energy has been expended to produce steam, little additional energy is needed to raise the temperature and pressure of the steam to the point at which it can turn a turbine. Cogeneration requires only 7 to $14 \%$ more fuel than process steam generation (Archibald and Gabriel 1979, Pingrey and Waggoner 1979). The turbine can power an electrical generator or a mechanical drive train. As the temperature and pressure of the steam in the turbine drops to the desired level, the steam is bled off and used for process steam.

Cogenerated electricity is cheaper than commercial electricity because the energy lost at commercial plants in condensing is used as process steam in the cogenerating facility. The state change energy is lost to the atmosphere in a full-condensing facility. A full-condensing turbine-generator is $36 \%$ energy efficient while a cogeneration facility is $81 \%$ energy efficient (Engelken and Farrell 1979), providing that all of the process steam is used. 


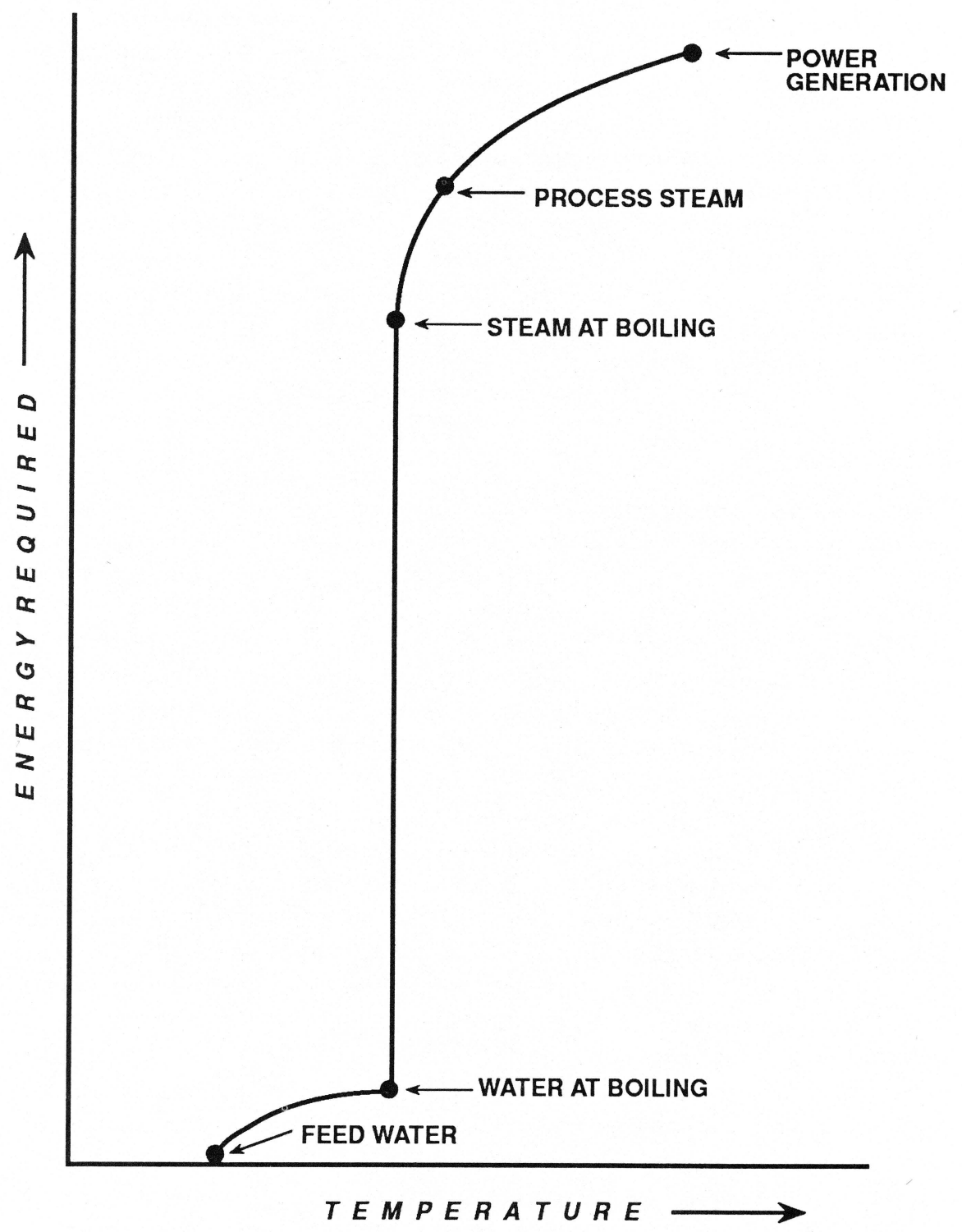

Figure 3. Generalized relationship between the energy requirement and the temperature of water and steam. 
The amount of electricity generated is determined by the difference between the inlet conditions and the exhaust conditions of the turbine. The preferred exhaust pressure to process steam is 50 to $150 \mathrm{psig}$. In 1979 it was reported that the inlet conditions ranged from 600 psig and 700 degrees $F$ to 1,450 psig and 950 degrees F (Archibald and Gabriel 1979, Engelken and Farrell 1979, Pingrey and Waggoner 1979). Brock et al. (1987) used a system with 250 psig inlet and 50 psig exhaust conditions in their analysis of the feasibility of cogeneration at West Virginia sawmills. The lower cost of the low pressure piping and boiler helped to counteract the negative effect inherent in the economies of scale of these low-production facilities.

Patterson and Brock (1986) developed an equation relating electricity usage in West Virginia sawmills to sawmill size:

$$
Y=4760+2750 x+775 X,^{2}
$$

where: $\mathrm{Y}=$ monthly electricity usage $(\mathrm{KWH})$, and

$\mathrm{X}=$ sawmill size in million board feet of lumber (MMBF).

This equation can be used to estimate the amount of electricity a cogenerating facility must produce for each mill size.

Amos (1975) reported that the Roseburg Lumber Company of Dillard, Oregon, used wood residues from their lumber, plywood, interior paneling, and flakeboard operation to power a 50 megawatt (MW) generator. The facility produces sufficient electricity and process steam for the entire plant.

It was reported (Anonymous 1977) that Georgia-Pacific Corporation's sawmill in Woodland, Maine, was electrically self-sufficient, using bark and wood residues as a fuel. The excess electricity was wheeled to the company's pulp and paper operation. The corporation's sawmill in Ft. Bragg, California, produced a surplus of electricity which was sold to the City of Ukiah.

By using wood residues and pulping liquors as fuel, Louisiana-Pacific Corporation's plant in Samoa, California, cogenerated enough electricity to supply a kraft pulp mill, a redwood sawmill, a studmill, a plywood plant, and a local town of 100 homes. An additional $5 \mathrm{MW}$ was sold to the regional utility (Taylor 1980).

The Vaagen Brothers Lumber Company of Corville, Washington, was in a unique situation. Their supplying utility was at capacity. To increase capacity, the utility would have had to produce electricity at a very high cost. Since Vaagen Brothers were located adjacent to a utility substation, they were able to sell all of their electrical production $(4 \mathrm{MW})$ to the utility at a high rate. The plant operators continued to buy the electricity they required from the utility at the original low rate (Northcross 1980).

Methven (1978) reported that Weyerhaeuser had 11 cogenerating facilities with 22 turbine-generators, and 25 other plants using steam turbines for mechanical drive rather than electricity. Hunt (1978) reported that Weyerhaeuser's Springfield, Oregon, plant was in a contractual agreement 
with the Eugene Water and Electric Board. The Board set up a turbine on land leased from Weyerhaeuser near the pulp mill's boiler. Weyerhaeuser supplied the steam for the turbine, and the spent steam was sent back to the mill. The board paid Weyerhaeuser for the steam and sold the electricity as its own. Weyerhaeuser bought electricity as an ordinary commercial customer. Tallman (1979) reported that Weyerhaeuser used back-pressure turbines at three plants (Aberdeen, Longview, and Everett) to produce $54 \mathrm{MW}$ each week, and supplied nine industrial customers. Bonneville Power Administration delivered the energy to the customers, charging for delivery and any load shaping or storage services needed.

Berry (1989) reported that a cogeneration facility was being constructed at Boise Cascade's Rumford, Maine, pulp and paper mill. The facility will burn southern coal and northern wood chips in a limestone fluidized bed combustor to supply $75 \mathrm{MW}$ to the Central Maine Power Company. The process steam will be used to heat the mill, the incoming water, and the drying drums on the paper machine.

New considerations were added to the evaluation of cogeneration systems with the passage of the Public Utility Regulatory Policies Act of 1978 (Euchner 1987). This act mandated that utilities must buy all power offered by any qualifying cogenerators at rates that are just and reasonable, and that utilities must sell required power to qualifying facilities under the same conditions and without discrimination.

Rulings published in the February 25, 1980, Federal Register stated that utilities must pay rates reflecting the avoided costs of the electricity purchased. This is the cost that the utility would have had to pay to produce that increment of power. If the utility is below capacity, the avoided cost is low because the utility is avoiding only the energy cost. If the utility is at capacity, the avoided cost is high, because to produce that increment of power, the utility would have to build a new generating facility. In this case, the avoided cost would include the energy cost plus capacity cost. In West Virginia, there is excess capacity; therefore, the avoided cost is low (Brock et al. 1987).

There are more things to consider than just capital and fuel costs in determining the desirability of cogeneration. There are line losses, interconnection costs, supplemental power, back-up power, and maintenance power to be considered. These terms are discussed in Appendix A. 


\section{GASIFICATION}

\section{Basics of Wood Gasification}

Wood gasification is an oxidation/pyrolysis process by which wood cellulose, hemicellulose, and lignin are broken down into simpler chemical components, including both gases and volatile liquids. The gases produced typically include hydrogen $\left(\mathrm{H}_{2}\right)$, carbon monoxide $(\mathrm{CO})$, carbon dioxide $\left(\mathrm{CO}_{2}\right)$, methane $\left(\mathrm{CH}_{4}\right)$, ethylene $\left(\mathrm{CH}_{4}\right)$, and ethane $\left(\mathrm{C}_{2} \mathrm{H}_{6}\right)$. Liquids include levoglucosan, carboxylic acids, and aromatics, including benzene, naphthalene, and anthracene (Beck 1979).

The process also produces substantial volumes of steam, mostly from moisture in the feedstock, and nitrogen, mostly from air used to effect combustion. Water, nitrogen, and carbon dioxide are, of course, noncombustible and represent "impurities" in the gas, which will lower its Btu content in subsequent combustion. The more sophisticated gasifiers are designed to generate secondary reactions involving water, carbon dioxide, and free carbon to produce larger proportions of hydrogen and carbon monoxide in the ultimate gas mixture, thus upgrading its Btu content.

The specific mix of gasification products varies according to the technical design of the gasifier and variables related to process control. The simpler and less costly processes produce gas with relatively low Btu content (less than 200 Btu per Standard Cubic Foot), while more sophisticated processes may produce gas in the 200-500 Btu/SCF range, compared with a standard of 1,000 Btu/SCF for natural gas (Groves and Anthony 1979).

In sophisticated gasifiers, liquids produced in gasification are subjected to secondary reactions to convert portions of them to combustible gas. Under certain conditions, the liquids may be used directly as combustibles ("closecoupled" use of the gas-volatile liquid stream in suitable boilers). In other applications, they must be scrubbed from the gas before it can be used (Overend 1979).

In past eras, gasifier gas has been used to power industrial machinery, operate cars, trucks, and tractors, and even as domestic heating and lighting fuel. In all of these types of uses, it has been almost totally superseded by fossil fuel or electricity. Under current technological and economic conditions, the use of gasifier gas is likely to be limited and specialized. The most obvious and economically efficient current prospect would be to use it as an energy resource at or very near the site of gas production. This type of "close-coupled" use avoids high transportation costs, which would put this gas at an economic disadvantage in relation to natural gas and other high Btu fuels. In addition, volatile liquids do not have to be cleaned (scrubbed) from the gas, provided the burners in which it is used are designed and adjusted to completely oxidize 
these components. Sensible heat generated during gasification can provide further energy in the utilization of the gas, provided that it is piped directly from the gasifier to the burner, which enhances the realized energy yield, or thermal efficiency, of the gasification process (Reed et al. 1979).

Uses which are not close-coupled would necessarily involve transporting and storing the gas. This would require scrubbing ungasified volatile liquids from the gas and, for efficient tank storage and transportation, condensation or liquifaction. Given the relatively low Btu yield of gasifier gas, these modes of utilization are not competitive with natural and bottled petroleum gas under current or readily foreseeable economic conditions.

\section{Components of Complete Gasification Systems}

The heart of a wood gasification system is the gasifier vessel or reactor. The overall size of a particular reactor will be determined primarily by the gas output capacity desired. In the past, small, low-output gasifiers have been built to be mounted directly on cars, trucks, and tractors. By contrast, a contemporary experimental fluidized bed gasifier has a reactor vessel measuring some 7 by 21 feet (Welch 1979).

A complete system will require equipment for fuel storage, handling, preparation and drying; blowers, piping, and monitoring and control equipment for air and gas; ash handling and disposal equipment; and, for clean gas applications, gas cooling and cleaning equipment (Overend 1979). All major components should be designed to work together efficiently. Appendix B of this report includes sources for guidelines on engineering, design and project feasibility analysis for wood-fueled energy systems and lists of wood energy system consultants and equipment vendors.

\section{Wood as a Gasifier Feedstock}

Established gasifier technologies readily process wood which meets particle size and moisture content specifications. Particle size should be relatively uniform. Any particular "run" of feedstock should be of reasonably uniform size. If the average particle size changes appreciably, adjustments must be made for most efficient reactor operation. Sawdust and fines, either alone or as the predominant material, are not acceptable gasifier feedstocks (J.P.R. Associates 1984, Reed et al. 1979, Technology Applications Laboratory 1984).

Most gasifiers require wood feedstock to have a moisture content of $30 \%$ or less on entering the gasifier vessel. The energy content of the gasifier gas is relatively low, due mainly to its high nitrogen content. It may be lowered further if it contains water vapor (steam). A limited amount of water vapor comes from the process air, but most will come from the moisture in the feedstock. Most gasifiers will neither operate efficiently, nor produce the best 
possible gas, if the feedstock has greater than $30 \%$ moisture content: input moisture contents of 10-20\% are even better (Reed et al. 1979).

Bark and hogged solid wood material make quite acceptable gasification feedstocks, and there are no notable problems associated with species of wood used (Reed et al. 1979, Technology Applications Laboratory 1984).

\section{Health and Environmental Considerations}

Close-coupled gasifiers produce no emissions, other than stack gas from the boiler (Overend 1979), because of the completeness of fuel pyrolysis and oxidation in a properly designed and operated wood gasification system. This process requires adequate temperature and turbulence control, as well as correct fuel residence time. All of these factors can be controlled by proper boiler design. Proper ratios of fuel and combustion air must be used, and responsible, knowledgeable operators should be employed (Elliott 1984).

In clean gas applications, scrubbing and cooling are very important, since water vapor contaminated with tar-as much as $\mathbf{5 5 0}$ liters for one ton of green feedstock at $50 \%$ moisture content WB-must be removed. The condensate poses a serious disposal problem since it contains phenolic compounds, which are extremely toxic to marine life and may be carcinogenic to humans in large concentrations. This problem can be reduced by using dry fuel, or a type of gasifier which reduces tar through secondary reactions. Regulatory agencies should be consulted concerning proper methods for handling and disposal of any condensate that may be produced.

Another health concern is that producer gas contains carbon monoxide, a respiratory poison. Overend (1979) noted that the maximum concentration allowed for an 8 hour working day is $50 \mathrm{ppm}$, and that producer gas is explosive when mixed with oxygen. Recommendations to avoid these hazards include housing the gasifier in a separate, well-ventilated building, monitoring for carbon monoxide in enclosed spaces, and installing flame and explosion-proof motors, actuators, and switches wherever gas leakage is a possibility (Overend 1979). 


\section{METHANOL}

Methanol, or methyl alcohol $\left(\mathrm{CH}_{3} \mathrm{OH}\right)$, is a fuel alcohol which can be produced from a variety of hydrocarbon feedstocks, including natural gas, coal, wood, or other biomass materials. Currently, most commercial methanol plants use natural gas or coal as feedstock (Rowell and Hokanson 1979, Zerbe 1988).

The residue-to-methanol process begins with gasification of the feedstock. The gases produced are refined and purified to achieve a mixture of two volumes of hydrogen to one volume of carbon monoxide. Through a series of catalyst-assisted shift and synthesis reactions, these gases are converted to methanol (Rowell and Hokanson 1979, Thompson and Ceckler 1977).

Methanol has a variety of uses. Currently, about $50 \%$ of U.S. production is consumed in the production of formaldehyde. Most of the rest is used to produce solvents, acrylics, insecticides, fungicides, and textile fibers (Rowell and Hokanson 1979). As a fuel, methanol and its close cousin, ethanol, may be used in mixture with gasoline. Some types of racing cars use pure methanol fuel (Zerbe 1988). Methanol and ethanol have potential to substitute for petroleum fuels in internal combustion engines and other liquid fuel applications.

Producing methanol from wood is not currently a commercially promising venture. Existing production capacity is sufficient to meet present markets, and production of methanol is a high investment and operating cost venture. Rowell and Hokanson (1979) did a feasibility analysis for a commercial-size wood methanol plant. They estimated that a 50 million gallon per year plant would require a capital investment of $\$ 64$ million (1975 dollars). With realistic raw material and operating costs figured in, they estimated that methanol would have to sell at $\$ 0.77$ per gallon or more for the enterprise to be profitable. By comparison, methanol was selling for $\$ 0.44$ per gallon ( 1978 wholesale price).

Rowell and Hokanson (1979) noted further that production of methanol from wood is not competitive with production from natural gas or coal. Natural gas has a clear advantage because methanol production from natural gas is much simpler than from either coal or wood. Capital costs for a natural gas plant would be about one-third of that for a comparable wood plant. Moreover, production of methanol from either natural gas or coal is much more efficient than from wood. Rowell and Hokanson (1979) estimated plant efficiencies, expressed as heat value of methanol produced as a percent of total energy input, at $61 \%$ for natural gas, $59 \%$ for coal, and $38 \%$ for wood residues. Rowell and Hokanson (1979) conclude that, "It is technically feasible, but not economically attractive now, to produce methanol from wood residues." 


\section{ECONOMICS}

In-depth economic analyses of wood residues as an energy resource will be provided in Volume 2 of this bulletin: Wood Residues As an Energy ResourcePart II: Economics and Marketing. Below are some general economic facts concerning wood residue use.

The capital costs of a wood-fired boiler and supporting equipment are higher than the capital costs of a gas-fired or oil-fired system. The cost of wood residues is lower than that of the other fuels when compared on an equivalent Btu basis. In 1987, the cost of one million Btu was $\$ 1.12$ for dry wood residue, $\$ 5.63$ for natural gas, and $\$ 7.50$ for oil (Brock et al. 1987). Lin (1981) stated that if a gas-fired or oil-fired system were replaced by a wood-fired system using green chips costing $\$ 15$ to $\$ 20$ per ton, the results would be a rate of return of $42 \%$ per year for industry and $33 \%$ per year for educational institutions. In systems within the scale limits of wood residue fuels, wood delivers energy at a lower cost than coal (Tillman 1981).

Duke and Keenan (1983) found the economics of a wood-fired system to be most sensitive to the cost of the displaced fossil fuel and the heat value of the wood residue. Tillman (1979) stated that the economic value of using wood residues as a fuel depends upon the energy content of the fuel, the cost of building and operating a wood-fired system and the resulting savings from not using oil, and the cost of moving residues from place to place.

Several researchers have stated that the economics of installing a wood-fired system are very site-specific or project-specific (Brock et al. 1987, Walton et al. 1987, Armstrong and Brock 1988, Patterson et al. 1988). The variability is large for such factors as equipment costs, operating costs, wood fuel size and moisture content, costs of displaced fossil fuel, avoided cost of electricity, and the amount of steam needed. To obtain an accurate economic analysis for any wood-fired system, actual values applicable to the project should be used.

The problem of choosing a gasifier type and size is also site- and applicationspecific. Similarly, the choice of auxiliary equipment for handling fuel and process gas will depend not only on the type of gasifier, but also on fuel types and characteristics and intended use of the gas produced. Finally, the investment and operation cost of any gasification system, in relation to alternative energy systems, will be a determining factor regarding whether gasification is a desirable energy system.

Pelletizing of sawdust and other fine residues is an excellent way to prepare residue for use as an energy resource. This is the only way that these residues can be used by some combustion facilities. The disadvantage of pelletization is the processing cost. This must be borne in mind and a full feasibility study conducted before undertaking a wood densification enterprise in lieu of less capital-intensive methods of handling and preparing wood residues for use as a fuel. 


\section{SUMMARY}

Wood residues can be used as an energy resource. They are widely available, cheaper than other fuels, usually reliably supplied, renewable, produce little sulfur or other pollutants, and produce less ash than other solid fuels. However, they are bulky, expensive to transport and store, have high moisture contents and variable particle sizes, and may cause dust problems. There may also be competing uses for the residues. For the forest products industry, Mason (1975) put it this way: "wood residues represent an internally generated, secure, relatively pollution-free energy source."

Drying wood residues increases their fuel value. Processing them into uniformly sized and shaped particles increases ease of handling and their value as a fuel. Pelletizing does both of these as well as increasing the bulk density. It is an excellent way to change a less desirable residue into a high-value fuel.

Wood burns differently than coal. It contains more volatiles and therefore is more reactive than coal. Even though the two fuels burn differently, they can be co-fired. By burning wood with coal, the amounts of sulfur dioxide and other pollutants are reduced as well as the volume of ash.

Currently, gasification (except in close-coupled applications) and methanol are not overly attractive energy resource options for wood residues. However, conditions may change. Mares (1981) stated that the federal government was committed to encouraging unconventional gas and synthetic fuels production. With changes in supplies and prices of competitive fuels, wood residues may become a viable feedstock for this segment of the energy industry.

The authors believe that wood residues are a viable energy resource. Some of the problems concerning the use of wood residues have been pointed out, not to be harsh on wood, but because the authors believe in an old saying: "If you do not know what the problem is, you are the problem." If the problems are known, technologies can be used to overcome or eliminate them. The advantages far outweigh the disadvantages. 


\section{LITERATURE CITED}

Amos, J. 1975. Medium size mixed fuel boilers. Wood residue as an energy source: Forest Products Research Society Proceedings P-75-13. pp 85-88.

Andrew, J.G. 1979. Fluidized bed combustion-an overview. Hardware for energy generation in the forest products industry: Forest Products Research Society Proceedings P-79-22: 95-98.

Anonymous. 1977. G-P sawmills generate surplus electricity. Tappi 60(9):33. Anonymous. 1979. Cogeneration and wood fuel united. Wood \& Wood Prod. 84(12):50.

Archibald, W.B. and J.A. Gabriel. 1979. Economics of cogeneration. Hardware for energy generation in the forest products industry: Forest Products Research Society Proceedings P-79-22. pp 24-27.

Armstrong, J.P. and S.M. Brock. 1988. Fuel consumption for kiln drying Appalachian hardwoods. WV Ag \& For Exper. Stat. Bulletin 698. 24 pp.

Beck, S. 1979. An overview of wood gasification. Technology and Economics of Wood Residue Gasification. Tex For. Prod. Lab., Tex. For. Svce. Lufkin, TX. pp 29-37.

Beisswenger, H., S. Darling, L. Plass, and A. Wechsler. 1985. Burning multiple fuels and following load in the Lurgi/combustion engineering circulating fluid-bed boiler. Proceedings of the eighth international conference on fluidized-bed combustion. Volume II DOE/METC-85/6021:2, pp. 619-633.

Berry, J.M. 1989. Competition opens a new chapter for Maine paper mill. The Washington Post. Sunday, Sept. 3. pp H2.

Brock, S.M., D.W. Patterson, and J.O. Raun. 1987. Economic feasibility of cogeneration at sawmills in West Virginia. WV Ag \& For Exper. Stat. Bulletin $697.29 \mathrm{pp}$.

Bulpitt, W.S. and J.L. Walsh Jr. 1982. Fuel handling and storage. The sixth international FRPS industrial wood energy forum ' 82 Vol. 1: Forest Products Research Society Proceedings 7334: 187-191

Callas, B. and J. Haygreen. 1987. An analysis of the densified wood fuel industry in the lake states. Minnesota Ag Exper Stat Miscellaneous Publication 42-1987: $31 \mathrm{pp}$.

Callas, B. 1988. Economic analysis of compression drying green wood chip fuels. Minnesota Ag Exper Stat Miscellaneous Publication 57-1988: 13 pp.

Chen, P.Y.S., J.G. Haygreen, and M.A. Graham. 1989. An evaluation of wood/coal pellets made in a laboratory pelletizer. For Prod J 39(7/8):53-58. 
Cobb, A. B. 1982. Fuel preparation for waste wood boilers. The sixth international FPRS industrial wood energy forum '82 Vol. 1: Forest Products Research Society Proceedings 7334: pp. 197-199.

Corder, S. E. 1975. Fuel characteristics of wood and bark and factors affecting heat recovery. Wood residues as an energy source: Forest Products Research Society Proceedings P-75-13: pp. 30-34.

Crane, T.H. 1979a. Gasifier sizing. Technology and Economics of Wood Residue Gasification. Tex. For. Prod. Lab., Tex. For. Svce. Lufkin, TX. pp 54-59.

Crane, T.H. 1979b. Production of low-BTU gases via a downdraft gasifier. Technology and Economics of Wood Residue Gasification. Tex. For. Prod. Lab., Tex. For. Svce. Lufkin, TX. pp 61-71.

Curtis, A.B. Jr. 1978a. Forest residues for energy in the south. USDA Forest Service, Jackson, Miss., 1978.

Curtis, A.B. Jr. 1978b. Fuel value calculator. USDA Forest Service, Southeastern Area State and Private Forestry.

Doty, E.L., V.J. Flanigan, and H.M. Freeman. 1979. Test results from cofiring wood waste in a small industrial boiler. Proceedings of the American Power Conference. 41:411-415.

Duke, L.D. and J.D. Keenan. 1983. Wood waste fuel in the secondary wood products industries. Energy 8(5):369-379.

Elliott, R.N. 1984. Wood Energy Information Guide (3rd). N.C. Agr. Extn. Svce., Extn. For. Tes., N.C. St. Univ., Raleigh, N.C. 93 pp.

Ellis, T.H. 1975. The role of wood residue in national energy picture. Wood residues as an energy source: Forest Products Research Society Proceedings P-75-13, pp. 17-20.

Engelken, L.J. and R.S. Farrell. 1979. Cogeneration: in-plant application. Hardware for energy generation in the forest products industry: Forest Products Research Society Proceedings P-79-22. pp 16-23.

Euchner, P.C. Jr. 1987. Fluidized bed combustion. ASHRAE Journal 29(2):20-25.

Fernie, A.D. 1979. Gasification systems-a case history. Hardware for energy generation in the forest products industry: Forest Products Research Society Procedings P-79-22. pp 120-125.

Finnie, G. 1979. Halycon gasification systems. Technology and Economics of Wood Residue Gasification. Tex. For. Prod. Lab., Tex. For. Svce. pp 90-98. 
Flanigan, V.J. 1980. Wood waste as a power plant fuel in the Ozarks Interagency Energy/Environment R\&D Program Report EPA-600/7-80-103, $74 \mathrm{pp}$.

Folk, R.L., R.L. Govett, L.R. Johnson, and H.W. Lee. 1988. Manufacturing and marketing of wood fuel pellets. Idaho For., Wldlf., and Range Expr. Stn. Tech. Rpt. No. 20. Moscow. 29 pp.

Freeman, M.L. and J.R. Short. 1982. Collection and delivery of mill residues. The sixth international FPRS industrial wood energy forum ' 82 Vol.1: Forest Products Research Society Proceedings 1:7334, pp. 58-59.

Goetzl, A. and S. Tatum. 1983. Wood energy use in the lumber and wood products industry. For Prod J 33(3):44-48.

Govett, R.L. and J.J. Meimban III. 1989. Potential for conversion of fossilfuel-fired boilers to use of wood fuel in schools, Hospitals, and State-owned building in Idaho. Paper presented at the 43rd Annual Meeting of the Forest Products Research Society in Reno, Nevada, on June 26-28, 1989.

Groves, J. and R.G. Anthony. 1979. History and state of gasification. Technology and Economics of Wood Residue Gasification. Tex. For. Prod. Lab., Tex. For. Svce. pp 1-19. Harris, R.A. 1989. Accelerated ambient airdrying of wood fuel. For Prod J 39(5):34-36.

Harris, R.A. 1982. Procurement options for wood fuel users. The sixth international FPRS industrial wood energy forum '82 Vol. 1: Forest Products Research Society Proceedings 1:7334, pp. 157-160.

Haygreen, J.G. 1981. Potential for compression drying of green wood chip fuel. For Prod J 31(8):43-54.

Haygreen, J.G. 1982. Mechanics of compression drying solid wood cubes and chip mats. For Prod J 32(10):30-38.

Helmer, W.A., K. Caraker, E.C. Workman, Jr., and J. Phelps. 1988. Effect of wood-to-coal fuel percent and underfire air on sulfur emissions and percent fuel energy loss during cofiring of wood and coal. For Prod J 38(11/12):49-54.

Host, J.R. and D.P.Lowery. 1970. Potential for using bark to generate steam power in western Montana. For Prod J 20(2):35-36.

Hunt, H.H. 1978. Utility industrial energy center. Increased energy from biomass: 1985 possibilities and problems, Proceedings from Pacific Northwest Bioconversion Workshop, Oct. 24-26, 1978. Published by U.S. Dept of Energy. pp 17-30. 
Jamison, R.L. 1979. Wood fuel use in the forest products industry. Progress in Biomass Conversion Vol.1. K.V. Sarkanen and D.A. Tillman, eds. Academic Press. New York, NY, pp 27-52.

Jasper, M.T. and P. Koch. 1975. Suspension burning of green bark to directfire high-temperature kilns for southern pine lumber. Wood residues as and energy source: Forest Products Research Society Proceedings P-75-13, pp. 70-72.

Jones, S.G. 1989. Personal Communication. Staff Supervisor-For Prod Util \& Marketing, Missouri Dept. of Conservation, Jefferson City, Mo.

Jordan, T.E., Jr. 1989. Wood to energy documentary. North Country Resource Conservation and Development Project, Inc. Newsletter. RFD \#4, Box 240, Meredith, New Hampshire, 03253-9416. pp 8.

J.P.R. Associates. 1984. Guidebook for Industrial/Commercial Wood Energy Conversion. J.P.R. Associates Consulting Foresters Specializing in the Use of Wood for Energy. Stowe, VT. 43 pp.

Junge, D.C. 1975. Boilers fired with wood and bark residues. Oregon St. U. For Res Lab Research Bulletin 17, pp. 11-59.

Kallmeyer, F.B. 1982. Particle reduction and classification, storage and reclamation. The sixth international FPRS industrial wood energy forum '82 Vol.1: Forest Products Research Society Proceedings 1:7334, pp. 208-209.

Keller, F.R. 1975. Fluidized bed combustion systems for energy recovery from forest products industry wastes. Wood residues as an energy source: Forest Products Research Society Proceedings P-75-13, pp. 73-78.

Koning, J.W.,Jr. and K.E. Skog. 1987. Use of wood energy in the United States-an opportunity. Biomass 12:27-36.

Lazare, E. and A.C. Campbell. 1989. Wood ash as a soil additive and liming agent. Paper presented at the 43rd Annual Meeting of the Forest Products Research Society in Reno, Nevada, on June 26-28, 1989.

Lin, Feng-Bor. 1981. Economic desirability of using wood as a fuel for steam production. For Prod J 31(1):31-36.

Lin, Feng-Bor. 1982. Wood-fired steam production at Clarkson College of Technology. Clarkson College of Technology. Potsdam, NY 73 pp.

Lin, Feng-Bor. 1983. Wood-fired steam production-a case study. For. Prod. J. 33(7/8):63-69.

Liu, Z. and J.G. Haygreen. 1985. Drying rates of wood chips during compression drying. Wood and Fiber Science 17(2):214-17. 
Manwiller, F.G. Unpublished data in Study File FS-So-3201-1.44, USDA Forest Service South. For. Exper. Stat., Pineville, LA.

Mares, J.W. 1981. The refocused energy policy: A natural gas perspective. U.S.Department of Energy Report CONF-810909-9, 8 pp.

Mason, R.L. 1975. Value of residues for fuel versus value for products. Wood residues as an energy source: Forest Products Research Society Proceedings P-75-13, pp. 27-29.

Methven, N.E. 1978. Existing cogenerating facilities. Increased energy from biomass: 1985 possibilities and problems, Proceedings from Pacific Northwest Bioconversion Workshop, Oct. 24-26, 1978. published by U.S. Dept. of Energy. pp 13-15.

Miller, E.C. and G.E. Hansen. 1951. Spreader stoker firing of wood and coal in multiple fuel furnaces. Proceedings of the Forest Products Research Society, pp. 195-201.

Moore, W.E. 1975. Mill residues: What are they really worth? Wood residue as an energy source: Forest Products Research Society Proceedings P-75-13, pp. 21-26.

Nelid, P.J. 1979. Suspension systems-an overview. Hardware for energy generation in the forest products industry: Forest Products Research Society Proceedings P-79-22, pp. 89-93.

Northcross, S. 1980. Cogeneration: a utilit(y)arian effort challenged among the independents. Timber Processing Industry. February.

Nor'west-Pacific Corp. 1981. Feasibility study for a forest-residue-fueled electric generating plant. Electric Power Research Institute TPS79-742: CS1819, $211 \mathrm{pp}$.

Oakes, E.J. 1982. Fluidized bed combustion provides for multifuel, economical cogeneration systems. Power Engineering 86(3):56-59.

Ostermeier, D.M., T.M. Young, and L.A. Weaver. 1988. Fossil fuels using industries: Their awareness and perception of wood fuel. For Prod J 38(10):53-58.

Overend, R. 1979. Gasification-an overview. Hardware for energy generation in the forest products industry: Forest Products research Society Procedings P-79-22. pp 107-119.

Patterson, D.W. and S.M. Brock. 1986. Electricity usage and residues production at West Virginia sawmills. W. Va. Forestry Notes No.12, pp. 1-3. Patterson, D.W., J.P. Armstrong, and D.R. Walton. 1988. Factors for economic analysis of installing hardwood kilns. For Prod J 38(2):38-40. 
Patterson, D.W. 1988. Wood residues from the forest products industry in West Virginia: Amounts, location, and availability. WV Ag. and For. Exper. Stat. Circular 145, 30 pp.

Petchul, V.C. 1988. Kraft linerboard mill versatile system. ASHRAE Journal 30(2):30-31.

Pingrey, D.W. and N.E. Waggoner. 1979. Cost effectiveness and incentivies for cogeneration. Hardware for energy generation in the forest products industry: Forest Products Research Society Proceedings P-79-22. pp 28-36.

Ramsdell, E.W. and R.E. Zawistowski. 1985. Design and performance of a multi-fuel boiler system. Tappi Journal 68(8):70-74.

Reed, T.B., D.E. Jantzen, W.P. Corcoran, and R. Witholder. 1979. Technology and economics of close-coupled gasifiers for retrofitting gas/oil combustion units to biomass feedstocks. Technology and Economics of Wood Residue Gasification. Tex. For. prod. Lab., Tex. For. Svce. pp 38-53.

Reese, R.G. 1975. The application of dry scrubbers to waste wood fired boilers. Wood residue as an energy: Forest Products Research Society Proceedings P-75-13, pp. 66-69.

Reineke, L.H. 1961. Wood fuel combustion practice. USDA Forest Products Lab Report No. 1666-18, 9 pp.

Rowell, R.M. and A.E. Hokanson. 1979. Methanol from wood: a critical assessment.Progress in Biomass Conversion Vol. 1., K.V. Sarkanen and D.A. Tillman, eds. Academic Press. NY pp 117-143.

Sarles, R.L. and J.P. Rutherfoord. 1982. Converting small industrial boilers to burn wood fuels. USDA Forest Service NEFES Research Paper NE-508, 10 pp.

Smith, D.J. 1985. Advances in fluidized bed combustion and cogeneration. Power Engineering 89(10):26-32.

Steklenski, P.G., D.L. Schmidt, and J.G. Haygreen. 1989. Properties of compression dewatered and baled aspen wood chip fuels. For Prod J 39(2):8-13.

Southworth, R. 1979. Suspension burning over hogged fuel in heat source and boiler: Case history. Hardware for energy generation in the forest products industry: Forest Products Research Society Proceedings P-79-22, pp. 94.

Tallman, R.J. 1979. Cogeneration in the Pacific Northwest. Hardware for energy generation in the forest products industry: Forest Products Research Society Proceedings P-79-22. pp 12-15. 
Tardif, G. 1979. Fluid bed system: A case history. Hardware for energy generation in the forest products industry: Forest Products Research Society Proceedings P-79-22, pp. 99-106.

Taylor, C.E. 1980. L-P uses wastewood for optimum power generation. Tappi 63(1):37-38.

Technology Applications Laboratory. 1984. The Industrial Wood Energy Handbook. Ga. Inst. of Tech., Engr. Expr. Stn. Van Nostrand Reinhold Co. NY 240 pp.

Thompson, E.V. and W.H. Ceckler. 1977. Introduction to Chemical Engineering. McGraw-Hill. NY. 401 pp.

Tillman, D.A. 1979. The economic values of wood residues as fuel. Progress In Biomass Conversion Vol. 1. K.V. Sarkanen and D.A. Tillman, eds. Academic Press,New York, NY, pp. 53-86.

Tillman, D.A. 1981. The relative desirability of several wood and coal energy options. Symposium Series of the American Institute of Chemical Engineers 77(207):72-77.

Toth, D.A. 1985. Fluidized bed at midwest solvents company-the economic edge. Proceedings of the eighth international conference on fluidized bed combustion. Volume II DOE/METC-85/6021-Vol.2, pp. 614-618.

U.S Department of Energy. 1981. Draft northeast regional environmental impact statement: The potential conversion of forty-two powerplants from oil to coal or alternate fuels. DOE/EIS-0083-D, pp. 3-40 to 3-42.

Villesvik, G. and D. Tillman. 1983. Cofiring of dissimilar solid fuels: A review of some fundamental and design considerations. Proceedings of the American Power Conference Vol. 45, pp. 970-975.

Vosler, G.L. 1985. Alternative fuels for use in a hogged-fuel boiler. Tappi Journal 68(10):66-68.

Walton, D.R., D.W. Patterson, and J.P. Armstrong. 1987. EERS (Economic Evaluation of a Residue System): A model for analyzing the economics of installing a steam kiln and wood-fired boiler at a West Virginia sawmill. WV Ag and For Exper Stat Bulletin 696, 23 pp.

Welch, N.E. 1979. Status of the University of Missouri-Rolla fluidized bed gasifier program. Technology and Economics of Wood Residue Gasification. Tex. For. Prod. Lab., Tex. for. svce. Lufkin, TX. pp 72-89.

Westphal, J.L. 1983. A discussion of reduced fuel moistures and drying methods for wood fired boilers. Report given at the APA Western Technical Division Fall Meeting, Sept.22, 83-P-10, 12 pp. 
West Virginia Air Pollution Control Commission. 1974. West Virginia Administrative Regulations Chapters 16-20, Series II.

West Virginia Department of Natural Resources. 1988. Best management practices for handling untreated wood waste. WVDNR Water Quality Document.

White, M.S., M.L. Curtis, R.L. Sarles, and D.W. Green. 1983a. Effects of outside storage on the energy potential of hardwood particulate fuels: Part I Moisture content and temperature. For Prod J 33(6):31-38.

White, M.S., M.L. Curtis, R.L. Sarles, and D.W. Green. 1983b. Effects of outside storage on the energy potential of hardwood particulate fuels: Part II Higher and net heating values. For Prod J 33(11/12):61-65.

Young, T.M. and D.M. Ostermeier. 1987. A survey of nonforest products industrial wood energy users. For Prod J 37(2):57-61.

Young, T.M., D.M. Ostermeier, and D.W. Domenech. 1988. Average wood chip trucking costs for the Southeastern United States. Sou J of App For 12(4):267-269.

Zerbe, J.I. 1988. Biofuels: production and potential. Forum for Applied Research and Public Policy. Winter 1988. pp 38-47.

Zerbe, J.I. 1989. Biomass energy and the global environment. Paper presented at the 43rd Annual Meeting of the Forest Products Research Society in Reno, Nevada, on June 26-28, 1989. 


\section{APPENDIX A}

\section{ADDITIONAL COST ITEMS FOR COGENERATION}

Line losses are the amount of energy lost during transmission. The purchased amounts of electricity may replace a greater amount of electricity from the utility, a lesser amount, or the same amount depending on where the facility's energy enters the grid as compared to the utility's supply. The avoided cost rate should reflect this.

Interconnection costs are defined as the reasonable costs of connection, switching, metering, transmission, distribution, safety provisions and administrative costs incurred by the utility in connecting the facility. Each qualifying facility must reimburse the utility any interconnection costs on a nondiscriminatory basis with respect to other customers with similar load characteristics.

Supplementary power is the energy or capacity regularly used by the qualifying facility in addition to that which the facility is generating. The rate of sale should be the same as for a non-generating customer who is buying the same amount as the supplementary power.

Back-up power is the energy or capacity supplied to replace the energy normally generated by the facility at times of unscheduled outage. If the utility must reserve power to provide back-up service, the rates should cover the costs associated with that reservation. The utility cannot assume, without factual data, that all back-up customers will require back-up power simultaneously and at peak demand time. The rate should be similar to a non-generating customer buying back-up power.

Maintenance power is the energy or capacity supplied to replace the energy normally generated by the facility at times of scheduled outage. The rate will vary according to when the outage is scheduled. If the facility schedules the outage during a time the utility's other loads are low, they are taking unused production while if the outage is scheduled during periods of high loads, they are requiring additional capacity. The rates of the former should be reflective. 


\section{APPENDIX B}

Major Sources of Further Information on Wood Energy Systems, Consultants, and Equipment Vendors

Detailed descriptions, including schematics, of several types of wood gasification systems may be found in these cited sources:

$\begin{array}{ll}\text { Beck (1979) } & \text { Crane (1979a) } \\ \text { Fernie (1979) } & \text { Finnie (1979) } \\ \text { Lin (1982) } & \text { Lin (1983) } \\ \text { Overend (1979) } & \text { Reed et. al. (1979) } \\ \text { Technology Applications } & \text { Laboratory (1984) } \\ \text { Welch (1979) } & \end{array}$

Guidelines on engineering designs and feasibility analysis for gasifiers and other wood-fueled energy systems may be found in these cited sources:

Crane (1979b)

Elliott (1984)

Overend (1984)

Technology Applications Laboratory (1984)

Listings of wood energy system consultants and equipment vendors may be found in these cited sources:

Elliott (1984)

Groves and Anthony (1979)

Reed et. al. (1979)

Technology Applications Laboratory (1984) 
Blank Page in Original Bulletin 


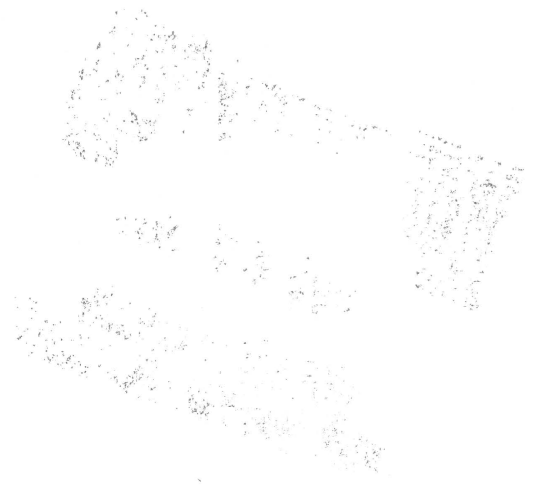

